\title{
Preclinical Development of PQR514, a Highly Potent PI3K Inhibitor Bearing a Difluoromethyl-Pyrimidine Moiety
}

Chiara Borsari $^{\dagger \$}$, Denise Rageot ${ }^{\dagger \$}$, Florent Beaufils ${ }^{\$ \$}$, Thomas Bohnacker ${ }^{\dagger \$}$, Erhan Keles ${ }^{\dagger}$, Ivan Buslov ${ }^{\dagger}$, Anna Melone ${ }^{\dagger}$, Alexander M. Sele ${ }^{\dagger}$, Paul Hebeisen ${ }^{\star}$, Doriano Fabbro ${ }^{\ddagger}$, Petra Hillmann ${ }^{\ddagger}$, Matthias P. Wymann ${ }^{\dagger *}$

${ }^{\dagger}$ Department of Biomedicine, University of Basel, Mattenstrasse 28, 4058 Basel, Switzerland

†PIQUR Therapeutics AG, Hochbergerstrasse 60, 4057 Basel

\$Equal contribution: these authors have contributed equally

Table of contents

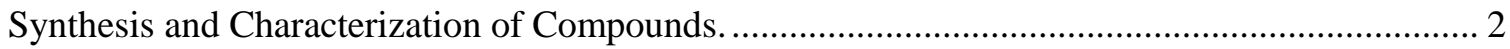

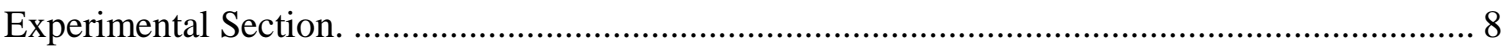

Table S1. Compiled Activity Data and Standard Errors (SEM) ................................................. 14

Table S2. Lipid Kinases and mTOR Binding Constants of PQR514 (4) and PQR309 (1) ........... 14

Figure S1. TREEspot ${ }^{\mathrm{TM}}$ Data Visualization of KINOMEScan Interactions of PQR514 (4) and

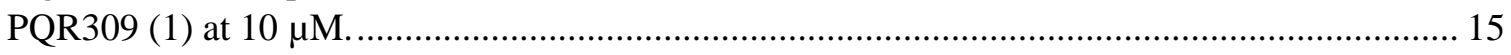

Table S3. Kinase Interactions of PQR514 (4) and PQR309 (1) at $10 \mu \mathrm{M}\left(\right.$ KINOMEscan $\left.^{\mathrm{TM}}\right) \ldots . . . .16$

Table S4. Selectivity Profile of PQR514 (4) Calculated from KinomeScan Data. ....................... 27

Table S5. In Vitro Pharmacology I - Ligand Binding Assays with PQR514 (4) at $10 \mu \mathrm{M}$.......... 28

Table S6. In Vitro Pharmacology II - Enzyme Assays with PQR514 (4) at $10 \mu \mathrm{M}$..................... 29

Table S7. Impact of PQR514 (4), PQR309 (1) and PQR530 (16) on cell proliferation................. 30

Table S8. Physicochemical Properties of PQR514 (4) ............................................................... 32

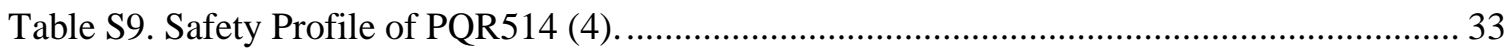

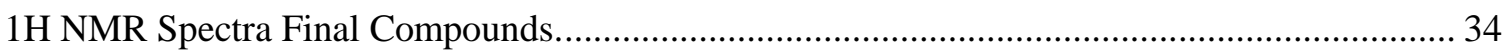

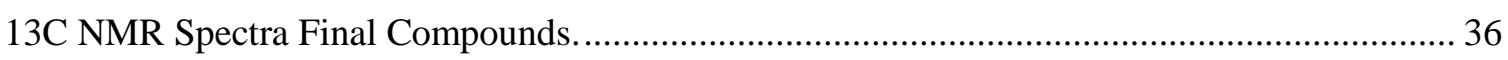

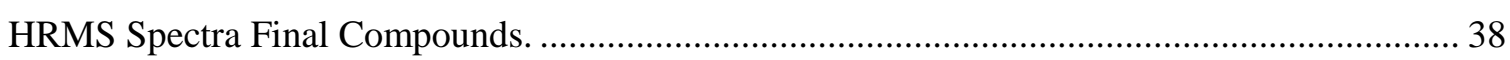

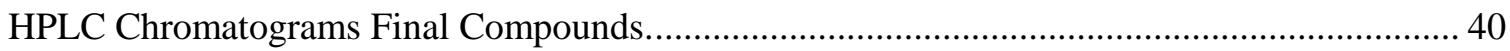

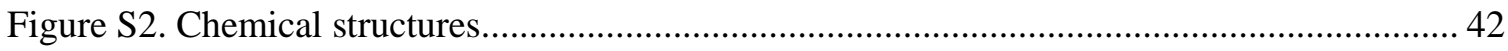




\section{Synthesis and Characterization of Compounds.}

General Information. Reagents were purchased at the highest commercial quality from Acros, SigmaAldrich or Fluorochem and used without further purification. Solvents were purchased from Acros Organics in AcroSeal ${ }^{\circledR}$ bottles over molecular sieves. Cross-coupling reactions were carried out under nitrogen atmosphere in anhydrous solvents, and glassware was oven dried prior to use. Thin layer chromatography (TLC) plates were purchased from Merck KGaA (Polygram SIL / UV254, $0.2 \mathrm{~mm}$ silica with fluorescence indicator) and UV light ( $254 \mathrm{~nm}$ ) was used to visualize the compounds. Column chromatographic purifications were performed on Merck KGaA silica gel (pore size $60 \AA$, 230-400 mesh particle size). Alternatively, flash chromatography was performed with Isco CombiFlash Companion systems using prepacked silica gel columns (40-60 $\mu \mathrm{m}$ particle size RediSep).

${ }^{1} \mathrm{H},{ }^{19} \mathrm{~F}$ and ${ }^{13} \mathrm{C}$ NMR spectra were recorded on a Bruker Avance 400 spectrometer. NMR spectra were obtained in deuterated solvents, such as $\mathrm{CDCl}_{3},\left(\mathrm{CD}_{3}\right)_{2} \mathrm{SO}$ or $\mathrm{CD}_{3} \mathrm{OD}$. The chemical shift ( $\delta$ values) are reported in ppm and corrected to the signal of the deuterated solvents (7.26 ppm ( $\left.{ }^{1} \mathrm{H} \mathrm{NMR}\right)$ and $77.16 \mathrm{ppm}\left({ }^{13} \mathrm{C} \mathrm{NMR}\right)$ for $\mathrm{CDCl}_{3} ; 2.50 \mathrm{ppm}\left({ }^{1} \mathrm{H} \mathrm{NMR}\right)$ and $39.52 \mathrm{ppm}\left({ }^{13} \mathrm{C} \mathrm{NMR}\right)$ for $\left(\mathrm{CD}_{3}\right)_{2} \mathrm{SO}$; and $3.31 \mathrm{ppm}\left({ }^{1} \mathrm{H} \mathrm{NMR}\right)$ and $49.00 \mathrm{ppm}\left({ }^{13} \mathrm{C} \mathrm{NMR}\right)$ for $\left.\mathrm{CD}_{3} \mathrm{OD}\right) .{ }^{19} \mathrm{~F}$ NMR spectra are calibrated relative to $\mathrm{CFCl}_{3}(\delta=0 \mathrm{ppm})$ as external standard. When peak multiplicities are reported, the following abbreviations are used: s (singlet), d (doublet), dd (doublet of doublets), $t$ (triplet), td (triplet of doublets), q (quartet), m (multiplet), br (broadened). Coupling constants, when given, are reported in Hertz (Hz).

High resolution mass spectra (HRMS) were recorded on a Bruker maxis $4 \mathrm{G}$, high resolution ESIQTOF. The chromatographic purity of final compounds was determined by high performance liquid chromatography (HPLC) analyses on an Ultimate 3000SD System from ThermoFisher with LPG3400SD pump system, ACC-3000 autosampler and column oven, and DAD-3000 diode array detector. An Acclaim-120 C18 reversed-phase column from ThermoFisher was used as stationary phase. Gradient elution (5:95 for $0.2 \mathrm{~min}, 5: 95 \rightarrow 100: 0$ over $10 \mathrm{~min}, 100: 0$ for $3 \mathrm{~min}$ ) of the mobile phase consisting of $\mathrm{CH}_{3} \mathrm{CN} / \mathrm{MeOH}: \mathrm{H}_{2} \mathrm{O}_{(10: 90)}$ was used at a flow rate of $0.5 \mathrm{~mL} / \mathrm{min}$ at $40{ }^{\circ} \mathrm{C}$. The purity of all final compounds was $>95 \%$.

General procedure 1. Bis(pinacolato)diboron (1.5 eq.), potassium acetate (3.0 eq.), [1,1'bis(diphenylphosphino)-ferrocene]dichloropalladium(II) $\left(\mathrm{Pd}(\mathrm{dppf}) \mathrm{Cl}_{2}, 0.10\right.$ eq.) and the bromo derivative 15 (1.0 eq.) were dissolved in absolute 1,4-dioxane (approx. $1 \mathrm{ml} / 0.2 \mathrm{mmol}$ ) under nitrogen atmosphere. The resulting mixture was heated at $95{ }^{\circ} \mathrm{C}$ for $0.5-1$ hour. The chlorotriazine derivative (1.0-1.1 eq.) and $\mathrm{K}_{2} \mathrm{CO}_{3}$ (3.0 eq.) were added. In a separate flask, palladium(II) acetate (Pd(OAc), 0.04 eq.) and triphenylphosphine ( $\mathrm{PPh}_{3}, 0.12$ eq.) were dissolved in tetrahydrofuran (THF) under nitrogen, stirred for $30 \mathrm{~min}$ and added to the reaction. The resulting mixture was stirred at $60{ }^{\circ} \mathrm{C}$ for $2-4 \mathrm{hrs}$. An aqueous $\mathrm{HCl}$-solution ( $3 \mathrm{M}, 10-15$ eq.) was added and stirred at $60^{\circ} \mathrm{C}$ for $2 \mathrm{hrs}$. After completion, the reaction was quenched with an aqueous $2 \mathrm{M} \mathrm{NaOH}$-solution and the product was extracted with DCM 
(3x). The combined organic layers were dried over $\mathrm{Na}_{2} \mathrm{SO}_{4}$, filtered and concentrated under reduced pressure. The crude was purified by column chromatography on silica gel.<smiles>Nc1ncc(-c2nc(N3CCOCC3)nc(N3CCOCC3)n2)c(C(F)F)n1</smiles>

4-(difluoromethyl)-5-(4,6-dimorpholino-1,3,5-triazin-2-yl)pyrimidin-2-amine (PQR514，4) was prepared according to general procedure 1 from 4,4'-(6-chloro-1,3,5-triazine-2,4-diyl)dimorpholine 9 (740 mg, $1.75 \mathrm{mmol}, 1.0$ eq.) and bromo derivative 15 (121 mg, $0.44 \mathrm{mmol}, 1.0$ eq.). Purification by column chromatography on silica gel (cyclohexane / ethyl acetate 1:2 $\rightarrow 1: 3$ ) gave compound $\mathbf{4}$ as a colorless solid (242 mg, $0.61 \mathrm{mmol}, 35 \%) .{ }^{1} \mathbf{H}$ NMR (400 MHz, $\left.\mathrm{CDCl}_{3}\right): \delta 9.20(\mathrm{~s}, 1 \mathrm{H}), 7.62\left(\mathrm{t},{ }^{2} J_{H, F}=\right.$ $54.3 \mathrm{~Hz}, 1 \mathrm{H}), 6.25$ (br s, $2 \mathrm{H}), 3.84(\mathrm{~s}, 7 \mathrm{H}), 3.75(\mathrm{dd}, J=5.6,3.9 \mathrm{~Hz}, 9 \mathrm{H}) .{ }^{19} \mathbf{F}\left\{{ }^{1} \mathbf{H}\right\} \mathbf{N M R}(376 \mathrm{MHz}$, $\left.\mathrm{CDCl}_{3}\right): \delta-121.77(\mathrm{~s}, 2 \mathrm{~F}) .{ }^{13} \mathbf{C}\left\{{ }^{1} \mathbf{H}\right\} \mathbf{N M R}\left(101 \mathrm{MHz}, \mathrm{CDCl}_{3}\right): \delta 167.49$ (s, $\left.1 \mathrm{C}\right), 165.50$ (s, $\left.1 \mathrm{C}\right), 164.50$ (s, $1 \mathrm{C}), 163.16(\mathrm{~s}, 1 \mathrm{C}), 161.88(\mathrm{~s}, 1 \mathrm{C}), 159.88\left(\mathrm{t},{ }^{2} J_{C, F}=21.8 \mathrm{~Hz}, 1 \mathrm{C}\right), 119.69$ (s, $\left.1 \mathrm{C}\right), 109.34\left(\mathrm{t},{ }^{1} J_{C, F}\right.$ $=241.1 \mathrm{~Hz}, 1 \mathrm{C}), 66.73(\mathrm{~s}, 4 \mathrm{C}), 43.66(\mathrm{~s}, 4 \mathrm{C}) . \mathbf{H R M S}(\mathrm{m} / z):[\mathrm{M}+\mathrm{H}]^{+}$calc. for $\mathrm{C}_{16} \mathrm{H}_{21} \mathrm{~F}_{2} \mathrm{~N}_{8} \mathrm{O}_{2} 395.1750$; found: 395.1744 . HPLC: $t_{\mathrm{R}}=6.94 \mathrm{~min}(96.7 \%$ purity).<smiles>CC1COCCN1c1nc(-c2cnc(N)nc2C(F)F)nc(N2CCOCC2)n1</smiles>

(S)-4-(difluoromethyl)-5-(4-(3-methylmorpholino)-6-morpholino-1,3,5-triazin-2-yl)pyrimidin-2amine (5) was prepared according to literature. ${ }^{16}$<smiles>C[C@H]1COCCN1c1nc(-c2cnc(N)nc2N2CCOCC2)nc(C(F)F)n1</smiles>

(R)-4-(difluoromethyl)-5-(4-(3-methylmorpholino)-6-morpholino-1,3,5-triazin-2-yl)pyrimidin-2-

amine (6) was prepared according to general procedure 1 from $(R)$-4-(4-chloro-6-morpholino-1,3,5triazin-2-yl)-3-methylmorpholin 11 (230 mg, $0.77 \mathrm{mmol}, 1.0 \mathrm{eq}$ ) and bromo derivative 15 (325 mg, 0.77 
mmol, 1.0 eq.). Purification by column chromatography on silica gel (cyclohexane / ethyl acetate 1:0 $\rightarrow$ 3:2) gave compound 6 as a colorless solid (196 mg, $0.48 \mathrm{mmol}, 62 \%) .{ }^{1} \mathbf{H} \mathbf{N M R}\left(400 \mathrm{MHz}, \mathrm{CDCl}_{3}\right): \delta$ $9.24(\mathrm{~s}, 1 \mathrm{H}), 7.65\left(\mathrm{t},{ }^{2} J_{H, F}=54.5 \mathrm{~Hz}, 1 \mathrm{H}\right), 6.13(\mathrm{br} \mathrm{s}, 2 \mathrm{H}), 4.77-4.71(\mathrm{~m}, 1 \mathrm{H}), 4.42-4.37(\mathrm{~m}, 1 \mathrm{H}), 3.99$ $\left(\mathrm{dd}, J_{H, H}=11.4,3.7 \mathrm{~Hz}, 1 \mathrm{H}\right), 3.88-3.80(\mathrm{~m}, 4 \mathrm{H}), 3.81-3.66(\mathrm{~m}, 6 \mathrm{H}), 3.53\left(\mathrm{td}, J_{H, H}=11.9,3.0 \mathrm{~Hz}, 1\right.$ $\mathrm{H}), 3.28\left(\mathrm{td}, J_{H, H}=13.0,3.8 \mathrm{~Hz}, 1 \mathrm{H}\right), 1.33\left(\mathrm{~d}, J_{H, H}=6.9 \mathrm{~Hz}, 3 \mathrm{H}\right) .{ }^{19} \mathbf{F}\left\{{ }^{1} \mathbf{H}\right\} \mathbf{N M R}\left(376 \mathrm{MHz}, \mathrm{CDCl}_{3}\right)$ : $\delta-121.65$ (s, 2 F). ${ }^{13} \mathbf{C}\left\{{ }^{1} \mathbf{H}\right\}$ NMR $\left(101 \mathrm{MHz}, \mathrm{CDCl}_{3}\right): \delta 167.64$ (s, $\left.1 \mathrm{C}\right), 164.56$ (s, $\left.1 \mathrm{C}\right), 164.20$ (s, 1 C), $163.43(\mathrm{~s}, 1 \mathrm{C}), 162.51(\mathrm{~s}, 1 \mathrm{C}), 159.46\left(\mathrm{t},{ }^{2} J_{C, F}=21.4 \mathrm{~Hz}, 1 \mathrm{C}\right), 119.71\left(\mathrm{t},{ }^{3} J_{C, F}=3.8 \mathrm{~Hz}, 1 \mathrm{C}\right), 109.52$ (t, $\left.{ }^{1} J_{C, F}=240.9 \mathrm{~Hz}, 1 \mathrm{C}\right), 71.00$ (s, $\left.1 \mathrm{C}\right), 66.94$ (s, $\left.1 \mathrm{C}\right), 66.74$ (s, $2 \mathrm{C}$ ), 46.48 (s, $1 \mathrm{C}$ ), 43.64 (br s, 2 C), 38.60 (s, $1 \mathrm{C}$ ), 14.32 (s, $1 \mathrm{C}$ ). HRMS ( $\mathrm{m} / \mathrm{z}$ ): $[\mathrm{M}+\mathrm{H}]^{+}$calc. for $\mathrm{C}_{17} \mathrm{H}_{23} \mathrm{~F}_{2} \mathrm{~N}_{8} \mathrm{O}_{2} 409.1907$; found: 409.1906 . HPLC: $t_{\mathrm{R}}=7.52 \min (>99.9 \%$ purity).

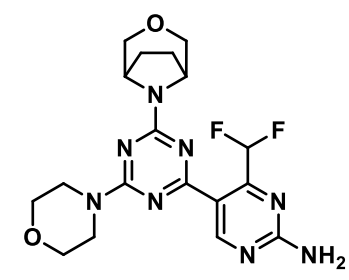

\section{5-(4-((1R,5S)-3-oxa-8-azabicyclo[3.2.1]octan-8-yl)-6-morpholino-1,3,5-triazin-2-yl)-4-}

(difluoromethyl)pyrimidin-2-amine (7) was prepared according to general procedure 1 from $(1 R, 5 S)$ 8-(4-chloro-6-morpholino-1,3,5-triazin-2-yl)-3-oxa-8-azabicyclo[3.2.1] octane 12 (130 mg, 0.42 mmol, $1.0 \mathrm{eq}$ ) and bromo derivative 15 (161 mg, $0.38 \mathrm{mmol}, 1.0$ eq.). Purification by column chromatography on silica gel (cyclohexane / ethyl acetate $3: 2 \rightarrow 1: 1$ ) gave compound 7 as a colorless solid ( $80 \mathrm{mg}, 0.19$ mmol, 50\%). ${ }^{1} \mathbf{H}$ NMR (400 MHz, $\left.\mathrm{CDCl}_{3}\right): \delta 9.24(\mathrm{~s}, 1 \mathrm{H}), 7.65\left(\mathrm{t},{ }^{2} J_{H, F}=54.5 \mathrm{~Hz}, 1 \mathrm{H}\right), 5.67$ (br s, 2 $\mathrm{H}), 4.73-4.64(\mathrm{~m}, 2 \mathrm{H}), 3.90-3.62(\mathrm{~m}, 12 \mathrm{H}), 2.13-1.97$ (m, $4 \mathrm{H}) .{ }^{19} \mathbf{F}\left\{{ }^{1} \mathbf{H}\right\}$ NMR $\left(376 \mathrm{MHz}, \mathrm{CDCl}_{3}\right): \delta$ - 121.51 (s, 2 F). ${ }^{13} \mathbf{C}\left\{{ }^{1} \mathbf{H}\right\}$ NMR (101 MHz, $\mathrm{CDCl}_{3}$ ): $\delta 167.87$ (s, $\left.1 \mathrm{C}\right), 164.67$ (s, $\left.1 \mathrm{C}\right), 163.39$ (s, $1 \mathrm{C}$ ), 162.64 (s, $1 \mathrm{C}), 162.45$ (s, 1 C), $159.53\left(\mathrm{t},{ }^{2} J_{C, F}=21.5 \mathrm{~Hz}, 1 \mathrm{C}\right), 119.69(\mathrm{~s}, 1 \mathrm{C}), 109.52\left(\mathrm{t},{ }^{1} J_{C, F}=240.9\right.$ Hz, 1 C), 71.90 (s, 1 C), 71.58 (s, 1 C), 66.74 (s, 2 C), 54.96 (s, 1 C), 54.52 (s, 1 C), 43.61 (br s, 2 C), 26.95 (s, $1 \mathrm{C}), 26.80$ (s, $1 \mathrm{C}$ ). HRMS (m/z): $[\mathrm{M}+\mathrm{H}]^{+}$calc. for $\mathrm{C}_{18} \mathrm{H}_{23} \mathrm{~F}_{2} \mathrm{~N}_{8} \mathrm{O}_{2} 421.1907$; found: 421.1907 . HPLC: $t_{\mathrm{R}}=7.49 \min (98.9 \%$ purity). 
<smiles>Nc1ncc(-c2nc(N3CCOCC3)nc(-n3cccc3)n2)c(C(F)F)n1</smiles>

\section{5-(4-((1R,5S)-8-oxa-3-azabicyclo[3.2.1]octan-3-yl)-6-morpholino-1,3,5-triazin-2-yl)-4-}

(difluoromethyl)pyrimidin-2-amine (8) was prepared according to general procedure 1 from $(1 R, 5 S)$ 3-(4-chloro-6-morpholino-1,3,5-triazin-2-yl)-8-oxa-3-azabicyclo[3.2.1]octane 13 (90 mg, 0.29 mmol, $1.1 \mathrm{eq})$ and bromo derivative 15 (112 mg, $0.26 \mathrm{mmol}, 1$ eq.). Purification by column chromatography on silica gel (cyclohexane / ethyl acetate $3: 2 \rightarrow 1: 1$ ) gave compound $\mathbf{8}$ as a colorless solid (49 mg, 0.12 mmol, 44\%). ${ }^{1} \mathbf{H}$ NMR (400 MHz, $\left.\mathrm{CDCl}_{3}\right): \delta 9.23$ (s, $\left.1 \mathrm{H}\right), 7.64\left(\mathrm{t},{ }^{2} J_{H, F}=54.5 \mathrm{~Hz}, 1 \mathrm{H}\right), 5.63$ (br s, 2 H), 4.48-4.42 (m, 2 H), 4.39-4.29 (m, 2 H), 3.88-3.74 (m, 8 H), 3.25-3.17 (m, 2 H), 1.97-1.93 (m, 2 H), 1.79-1.74 (m, $2 \mathrm{H}) .{ }^{19} \mathbf{F}\left\{{ }^{1} \mathbf{H}\right\}$ NMR $\left(376 \mathrm{MHz}, \mathrm{CDCl}_{3}\right): \delta-121.43$ (s, $\left.2 \mathrm{~F}\right) .{ }^{13} \mathbf{C}\left\{{ }^{1} \mathbf{H}\right\} \mathbf{N M R}(101 \mathrm{MHz}$, $\mathrm{CDCl}_{3}$ ): $\delta 166.41$ (s, $1 \mathrm{C}$ ), 164.58 (s, $1 \mathrm{C}$ ), 163.39 (s, $1 \mathrm{C}$ ), 162.29 (s, $1 \mathrm{C}$ ), 161.49 (s, $1 \mathrm{C}$ ), 158.49 (t, $\left.{ }^{2} J_{C, F}=21.4 \mathrm{~Hz}, 1 \mathrm{C}\right), 118.90(\mathrm{~s}, 1 \mathrm{C}), 108.46\left(\mathrm{t},{ }^{1} J_{C, F}=240.7 \mathrm{~Hz}, 1 \mathrm{C}\right), 72.81$ (s, $\left.1 \mathrm{C}\right), 72.79$ (s, $\left.1 \mathrm{C}\right)$, 65.72 (s, 2 C), 48.35 (s, 1 C), 48.10 (s, 1 C), 42.62 (br s, 2 C), 28.68 (s, 1 C), 26.67 (s, 1 C). HRMS $(m / z):[\mathrm{M}+\mathrm{H}]^{+}$calc. for $\mathrm{C}_{18} \mathrm{H}_{23} \mathrm{~F}_{2} \mathrm{~N}_{8} \mathrm{O}_{2}$ 421.1907; found: 421.1900. HPLC: $t_{\mathrm{R}}=7.33$ min (> 99.9\% purity).<smiles>Clc1nc(N2CCOCC2)nc(N2CCOCC2)n1</smiles>

4,4'-(6-chloro-1,3,5-triazine-2,4-diyl)dimorpholine (9) was prepared according to literature. ${ }^{10}$<smiles>CC1COCCN1c1nc(Cl)nc(N2CCOCC2)n1</smiles>

(S)-4-(4-chloro-6-morpholino-1,3,5-triazin-2-yl)-3-methylmorpholine (10) was prepared according to literature. ${ }^{16}$ 
<smiles>C[C@@H]1COCCN1c1nc(Cl)nc(N2CCOCC2)n1</smiles>

(R)-4-(4-chloro-6-morpholino-1,3,5-triazin-2-yl)-3-methylmorpholine (11) was prepared according to literature. ${ }^{16}$

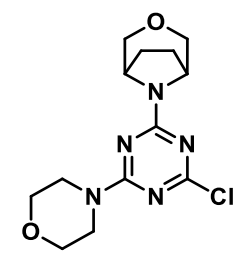

(1R,5S)-8-(4-chloro-6-morpholino-1,3,5-triazin-2-yl)-3-oxa-8-azabicyclo[3.2.1]octane (12) was prepared according to literature. ${ }^{16}$

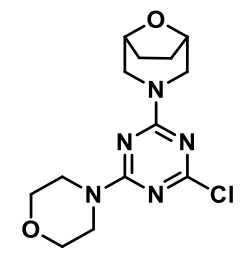

(1R,5S)-3-(4-chloro-6-morpholino-1,3,5-triazin-2-yl)-8-oxa-3-azabicyclo[3.2.1]octane (13) was prepared according to literature. ${ }^{16}$<smiles>Clc1nc(Cl)nc(N2CCOCC2)n1</smiles>

2,4-Dichloro-6-(morpholin-4-yl)-1,3,5-triazine (14) was prepared according to the literature. ${ }^{10}$ 
<smiles>CC(C)(C)OC(=O)N(C(=O)OC(C)(C)C)c1ncc(Br)c(C(F)F)n1</smiles>

tert-Butyl $\quad N$-[5-bromo-4-(difluoromethyl)pyrimidin-2-yl]- $N$-[(tert-butoxy)carbonyl]carbamate (15) was prepared according to the literature. ${ }^{16}$ 


\section{Experimental Section.}

\section{Structure Modeling of PI3K and mTOR Kinase Complexes}

The coordinates of PQR309 (1) in PI3K $\gamma$ complex (PDB code 5OQ4, resolution of $2.7 \AA$ ) was used as starting points to dock inhibitor PQR514 (4) into the ATP-binding site. The ligand in the crystal structure was manually replaced using Maestro 11.1 and energy minimization was carried out. Further measurements and figures were generated in Maestro 11.1 and Chimera UCSF.

\section{Determination of Inhibitor Dissociation Constants}

Dissociation constants of compounds $\left(K_{\mathrm{i}}\right)$ for $\mathrm{p} 110 \alpha$ and mTOR were determined by commercial LanthaScreen (Life Technologies) and evaluated as described in Ref. 11. Briefly, AlexaFluor647labeled Kinase Tracer314 (\#PV6087) with a $K_{\mathrm{d}}$ of $2.2 \mathrm{nM}$ was used at $20 \mathrm{nM}$ for $\mathrm{p} 110 \alpha$, and at a final concentration of $10 \mathrm{nM}$ for mTOR ( $K_{\mathrm{d}}$ of $19 \mathrm{nM}$ ). Recombinant N-terminally (His) $)_{6}$-tagged p110 $\alpha$ was detected with biotinylated anti-(His) 6 -tag antibody (2 nM, \#PV6089) and LanthaScreen Eu-Steptavidin (2 nM, \#PV5899); N-terminal GST fused to truncated mTOR (amino acids 1360-2549; \#PR8683B) was detected with a LanthaScreen Eu-labelled anti-GST antibody ( 2 nM, \#PV5594). The p110 $\alpha$ assay buffer was composed of $50 \mathrm{mM}$ HEPES pH 7.5, $10 \mathrm{mM} \mathrm{MgCl} 2,1 \mathrm{mM}$ EGTA, and 0.01\% (v/v) Brij-35, and the mTOR assay buffer contained $50 \mathrm{mM}$ HEPES; $5 \mathrm{mM} \mathrm{MgCl}_{2}$; $1 \mathrm{mM}$ EGTA; 0.01\% Pluronic F-127. Further details and calculations are explained in Ref. 10.

\section{Cellular PI3K and mTOR Signaling}

Downstream signals emerging from mTORC2 (phosphorylation of Ser473 of PKB/Akt; rabbit polyclonal antibody from Cell Signaling Technology (CST), \#4058) and mTORC1 (phosphorylation of Ser235/236 on the ribosomal protein S6; rabbit monoclonal antibody from CST, \#4856) were measured in In-Cell Western assays plating 2x104 A2058 cells/well in 96-well plates (Cell Carrier, Perkin Elmer) for $24 \mathrm{~h}\left(37^{\circ} \mathrm{C}, 5 \% \mathrm{CO}_{2}\right)$, before exposing cells for $1 \mathrm{~h}$ to inhibitors or DMSO. Then, cells were fixed (4\% PFA in PBS for 30 min at RT), blocked (1\% BSA/0.1\% Triton X-100/5\% goat serum in PBS for $30 \mathrm{~min}, \mathrm{RT}$ ), and stained with CST primary antibodies (1:500). Tubulin staining (mouse anti- $\alpha$-tubulin, 1:2000, Sigma \#T9026) was assessed as internal standard. Secondary antibody [IRDye680-conjugated goat anti-mouse, and IRDye800-conjugated goat anti-rabbit antibodies (LICOR \# 926-68070 and \# 92632211), both 1:500] fluorescence was detected on an Odyssey CLx infrared imaging scanner (LICOR). Remaining phospho-protein signals were normalized to cellular tubulin and related to DMSO controls. ICW analysis and determination of $\mathrm{IC}_{50}$ were done as described in Ref. 11. 


\section{Kinome Profiling}

The inhibitory capacity and selectivity of PQR514 (4) was determined using the ScanMax platform provided by DiscoverX. Briefly, binding of immobilized ligand to DNA-tagged kinases was competed with $10 \mu \mathrm{M}$ of PQR514 (4). The amount of kinase bound to the immobilized ligand was measured by quantitative PCR of the respective DNA tags and is given as percentage of control. Binding constants of PQR514 (4) for kinases of interest were determined by competing the immobilized ligand kinase interactions with an 11-point 3-fold serial dilution of compound starting from $30 \mu \mathrm{M}$ and subsequent quantitative PCR of DNA tags. Binding constants were calculated by a standard dose-response curve using the Hill equation (with Hill Slope set to -1):

Response $=$ Background $+($ Signal - Background $) /\left(1+10^{\wedge}([\lg\right.$ Kd $-\lg$ dose $] *$ HillSlope $\left.)\right)$

Selectivity scores were calculated as

$\mathrm{S}=$ Number of hits / Number of tested kinases (excluding mutant variants), where S35, S10, S1 were calculated using \%Ctrl as a potency threshold $(35,10,1 \%)$; for example

$\mathrm{S}(35)=($ number of non-mutant kinases with \% Ctrl <35)/(number of non-mutant kinases tested $)$.

\section{Determination of Cytochrome P450 Enzymes Inhibition}

The potential interaction of PQR514 (4) with the cytochrome P450 enzymes was assessed using Fluorescent High Throughput P450 assays (Gentest). IC $_{50}$ concentration inhibition of the most important isoenzymes (CYP1A2, CYP2C19, CYP2D6 and CYP3A4) was determined starting from $100 \mu \mathrm{M}$ concentration. Inhibition of the most important four P450 isoforms was measured in specific assays using specific substrates that become fluorescent upon CYP metabolism. Compound $\mathbf{4}$, dissolved in DMSO, was tested in duplicate $(\mathrm{n}=2)$ in concentration-response curves, eight concentrations, 1:3 dilutions starting from $100 \mu \mathrm{M}$ (100-33.3-11.1-3.7-1.25-0.41-0.14-0.046) in a 96-well plate containing incubation/NADPH regenerating buffer. Specific isoenzymes and substrates were added and incubated at $37{ }^{\circ} \mathrm{C}$. Reactions were terminated at different times, depending on the assays, and plates read on a Fluoroskan Ascent at the appropriate emission/excitation wavelengths. Concentration-response curves performed in duplicate for known inhibitors for each isoenzyme were tested in every assay as positive controls, 1:3 dilutions were performed starting from $100 \mu \mathrm{M}$ for furafylline and tranylcypromine, 1.66 $\mu \mathrm{M}$ for ketoconazole and $0.5 \mu \mathrm{M}$ for quinidine. The $\mathrm{IC}_{50}$ was determined by fitting a four parametric function using the Excel Solver.

\section{Viability Studies - 66 Cancer Cell Line Panel}

The NTRC Oncolines 66 cell lines were exposed for $72 \mathrm{~h}$ to 9-point 3-fold serial dilutions of PQR514 (4) as described in Ref. 10, 11 and 14. The $\mathrm{IC}_{50}$ s were calculated by non-linear regression using IDBS XLfit 5. The percentage growth after $72 \mathrm{~h}$ (\%-growth) was normalized as follows: 


$$
100 \% * \text { (luminescence } \mathrm{t}_{\mathrm{t}=72 \mathrm{~h}} / \text { luminescence }_{\text {untreated, } \mathrm{t}=72 \mathrm{~h}} \text { ). }
$$

This was fitted to a 4-parameter logistics curve:

$$
\% \text {-growth }=\text { bottom }+(\text { top }- \text { bottom }) /\left(1+10^{\wedge}[(\log \text { IC50 }-\log x) * \text { HillSlope }]\right),
$$

where bottom and top are the asymptotic minimum and maximum cell growth that the compound allows in that assay.

\section{Passive Permeability Evaluation}

The passive permeability of PQR514 (4) was assessed using artificial membranes (PAMPA) at pH 7.4. Solution of compound 4 (10 mM DMSO stock solution) was diluted in PBS buffer $\mathrm{pH} 7.4$ up to $50 \mu \mathrm{M}$ and incubated $(300 \mu \mathrm{l})$ in duplicates in the donor plate (96-well plate with porous filters pre-treated with the phospholipid solution 2\% Phosphatidylcholine in hexane:dodecane 1:1). Acceptor plate containing $270 \mu$ PBS buffer pH 7.4 was assembled with the donor plate. After 2 hours of incubation with gentle shaking (200 rpm), the two solutions were analyzed and quantified by LC-MS. Equilibrium solutions without the membrane layer were also prepared. Propranolol and cimetidine were added as reference standards. Samples were analyzed on UFLC Shimazu AC20 coupled with a API 3200 Triple Quadrupole ABSciex.

\section{Solubility Determination}

Thermodynamic solubility of PQR514 (4) in buffers at various $\mathrm{pH}$ (i.e. 1.2, 4.5 and 6.8) and in FasSIF and FesSIF fluids was determined by the shake flask method. Quantification of the samples was performed on a calibration curve prepared by dilution in ACN of a $50 \mathrm{mM}$ stock solution. Saturated solutions (with some deposit) of compound $\mathbf{4}$ were prepared by incubating the amount of $\mathbf{4}$ in approximately $0.2 \mathrm{ml}$ of buffer for $24 \mathrm{~h}$ at room temperature $\left(25^{\circ} \mathrm{C}\right)$ under agitation for the test at $\mathrm{pH}$ 1.2, 4.5 and 6.8; whereas samples were kept at $37{ }^{\circ} \mathrm{C}$ to better mimic the in vivo conditions for FaSSIF and FeSSIF buffers. After incubation samples were centrifuged at $12000 \mathrm{rpm}$ for $10 \mathrm{~min}$ and $200 \mu \mathrm{l}$ aliquot were filtered (Multiscreen HTS Millipore) diluted in ACN and each sample was then injected into LC-MS/MS.

\section{Metabolic stability in liver microsomes}

The stability of PQR514 (4) in human, rat, dog and mouse liver microsomes evaluating Phase I metabolism was assessed. Compound 4 in duplicate was dissolved in DMSO at $0.2 \mathrm{mM}$ and preincubated, at the final concentration of $1 \mu \mathrm{M}$, for $10 \mathrm{~min}$ at $37^{\circ} \mathrm{C}$ in potassium phosphate buffer $50 \mathrm{mM}$ $\mathrm{pH}$ 7.4, $3 \mathrm{mM} \mathrm{MgCl}_{2}$, with rat, human, dog and mouse liver microsomes (Xenotech) at the final concentration of $0.5 \mathrm{mg} / \mathrm{ml}$. After the pre-incubation period, reactions were started by adding the 
cofactors mixture (NADP, Glc6P, Glc6P-DH in 2\% Sodium bicarbonate); samples (50 $\mu$ l) were taken at time 0 and $30 \mathrm{~min}$ added to $150 \mu \mathrm{l}$ of cold $\mathrm{ACN}$ with Verapamil $0.02 \mathrm{uM}$ as Internal Standard (IS) to stop the reaction. After centrifugation the supernatants were analyzed by LC-MS/MS. Samples were analyzed on UFLC Shimazu AC20 coupled with an API 3200 Triple Quadrupole ABSciex. A control sample without cofactors was added in order to check the stability of test compounds in the matrix after $30 \mathrm{~min}$. 7-ethoxycoumarin and propranolol were added as reference standards.

\section{Metabolic stability in hepatocytes}

The stability of PQR514 (4) in human, rat, dog and mouse cryopreserved hepatocytes was assessed. Cryopreserved hepatocytes of pooled humans (batch HU8135), mouse (batch MC617), rat (batch RS743), dog (batch DB288) were obtained from Life Technology. Cells were thawed following the manufacturer's recommendations, resuspended in Williams' Medium E and Hepatocyte Maintenance Supplement at $\mathrm{pH} 7.4$ as described in the Provider instructions, and incubated for the experiments at 37 ${ }^{\circ} \mathrm{C}$ in incubator $\left(5 \% \mathrm{CO}_{2}\right)$. Clearance experiments were performed at $2.5 \mu \mathrm{M}$ final concentration of test compound 4 and $0.5 \times 10^{6}$ cells $/ \mathrm{mL}$. 7-Ethoxycoumarin and 7-hydroxycoumarin were tested as positive controls in the same experiments. Incubations were carried out in triplicate $(n=3)$ and samples were collected at time 0, 15, 30, 60 and 90 min. The reactions were stopped by addition of ACN containing Verapamil $0.01 \mu \mathrm{M}$ as internal standard. Proteins were removed by centrifugation (1000 $\mathrm{x} \mathrm{g}$ for $10 \mathrm{~min}$ at $10{ }^{\circ} \mathrm{C}$ ) and the supernatant fractions analyzed by LC-MS/MS. Samples were analyzed on UFLC Shimazu AC20 coupled with an API 3200 Triple Quadrupole ABSciex.

\section{Pharmacokinetic studies in male C57BL/6J mice}

Male C57BL/6J mice ( 8 weeks old at delivery) were purchased from Janvier Labs (France). The animals were housed in a temperature-controlled room $\left(20-24^{\circ} \mathrm{C}\right)$ and maintained in a $12 \mathrm{~h}$ light/12 hrs dark cycle. Food and water were available ad libitum throughout the duration of the study. The animals were checked for clinical signs throughout the study. No adverse effects were observed.

PQR514 (4) was dissolved first in DMSO. Tween 80 was added subsequently and finally, the formulation was completed with HP $\beta$ CD 20\% (hydroxypropyl-beta-cyclodextrin). The formulations were maintained under constant stirring. The formulations were administered via gavage at $\mathrm{t}=0 \mathrm{~h}$ using a feeding needle. During dosing the mice were slightly restrained. At each of 8 time points, three mice of each treatment group were anesthetized with isoflurane for blood sampling via puncture of the retrobulbar venous plexus. Blood was collected in tubes containing K3-EDTA and stored on ice until centrifugation at $3000 \mathrm{xg}\left(10 \mathrm{~min}, 4^{\circ} \mathrm{C}\right)$. The plasma supernatant was separated and kept at $-20^{\circ} \mathrm{C}$ until being assayed. Immediately after blood sampling, mice were sacrificed by inhalation of an overdose of isoflurane and tissues (thigh muscles and brain) were collected. 
The stock solutions of PQR514 (4) (1 mg/ml in DMSO) were diluted in DMSO to a final concentration of $100 \mu \mathrm{g} / \mathrm{mL}$ (start solution).

Preparation of plasma samples: A volume of $40 \mu \mathrm{l}$ acetonitrile containing the internal standard (150 $\mathrm{ng} / \mathrm{ml}$ Diazepam for 2015PQR002 samples and $300 \mathrm{ng} / \mathrm{ml}$ Griseofulvin for 2015PQR004 samples) was added to $20 \mu 1$ of mouse plasma sample, plasma calibration standard and plasma QC sample. Samples were vigorously shaken and centrifuged for 10 minutes at $6000 \mathrm{~g}$ and $20^{\circ} \mathrm{C}$. The particle free supernatant was diluted with 1 volume of water. An aliquot was transferred to $200 \mu \mathrm{l}$ sampler vials and subsequently subjected to LC-MS with an injection volume of $1.5 \mu 1$.

Preparation of brain samples: The brain samples were homogenized in PBS $(1: 2, \mathrm{w} / \mathrm{v})$ using the Precellys 24/Dual homogeniser. A volume of $40 \mu \mathrm{l}$ acetonitrile containing the internal standard (150 $\mathrm{ng} / \mathrm{ml}$ Diazepam for 2015PQR002 samples and $300 \mathrm{ng} / \mathrm{ml}$ Griseofulvin for 2015PQR004 samples) was then added to $20 \mu \mathrm{l}$ of brain homogenate, brain calibration standard and brain QC sample. Samples were vigorously shaken and centrifuged for 10 minutes at $6000 \mathrm{~g}$ and $20^{\circ} \mathrm{C}$. The particle free supernatant was diluted with 1 volume of water. An aliquot was transferred to $200 \mu \mathrm{l}$ sampler vials and subsequently subjected to LC-MS with an injection volume of $1.5 \mu \mathrm{l}$.

Preparation of thigh muscle samples: The muscle samples were homogenized in PBS (1:4, w/v) using the Precellys 24/Dual homogeniser. A volume of $40 \mu$ acetonitrile containing the internal standard (150 $\mathrm{ng} / \mathrm{ml}$ Diazepam for 2015PQR002 samples and $300 \mathrm{ng} / \mathrm{ml}$ Griseofulvin for 2015PQR004 samples) was then added to $20 \mu \mathrm{l}$ of muscle homogenate, muscle calibration standard and muscle QC sample. Samples were vigorously shaken and centrifuged for 10 minutes at $6000 \mathrm{~g}$ and $20^{\circ} \mathrm{C}$. The particle free supernatant was diluted with 1 volume of water. An aliquot was transferred to $200 \mu 1$ sampler vials and subsequently subjected to LC-MS with an injection volume of $1.5 \mu \mathrm{l}$.

Mass spectrometry was performed on Accela 1250 UHPLC system, Accela Open Autosampler, QExactive mass spectrometer (Thermo Fisher Scientific), data handling with the standard software Xcalibur 2.2.

Ethic statement: All experimental procedures were approved by and conducted in accordance with the regulations of the local Animal Welfare authorities (Landesamt für Gesundheit und Verbraucherschutz, Abteilung Lebensmittel- und Veterinärwesen, Saarbrücken).

\section{Quantification of insulin and glucose plasma levels in male C57BL/6J mice}

Plasma insulin: plasma insulin was quantified by UV/VIS spectrometry using a commercially available colorimetric immunoassay kit (Rat/Mouse Insulin ELISA, cat. no. EZRMI-13K, Merck Millipore, Germany), according to manufacturer's instructions. Samples were analysed without dilution or in a 2fold and 10-fold dilution in assay buffer; in order to cover the full range of sample concentrations. Original sample concentrations were interpolated from a calibration curve covering the range of $0.2-10$ $\mathrm{ng} / \mathrm{ml}$ using the software GraphPad Prism 5.0. 
Plasma glucose: plasma glucose was quantified by UV/VIS spectrometry using the Glucose Colorimetric Assay Kit (cat. no. Cay10009582-192, biomol, Germany), according to manufacturer's instructions, which is based on the glucose oxidase-peroxidase reaction. Samples were analysed in a 40fold dilution in assay buffer. Original sample concentrations were interpolated from a calibration curve covering the range of $2.5-25 \mathrm{ng} / \mathrm{ml}$ using Microsoft excel.

\section{In vivo toxicokinetic studies in Wistar rats and in Beagle dogs}

4-day range finding and 14-day pilot with PQR514 (4) by daily gavage in Wistar rats and Beagle dogs. The study was based on the following guidelines: i) ICH M3 (R2): Note for guidance on non-clinical safety studies for the conduct of human clinical trials and marketing authorization for pharmaceuticals, December 2009; ii) ICH Harmonised Tripartite Guideline S9: Nonclinical Evaluation for Anticancer Pharmaceuticals, November 2009.

Rats: PQR514 (4), formulated in 20\% (w/v) Hydroxypropyl-ß-cyclodextrin (HPßCD) in Elix water, was administered by oral gavage for 14 consecutive days to Wistar rats at dose levels of 0, 0.8, 1.6 and 2.4 $\mathrm{mg} / \mathrm{kg} /$ day in females and $0,1.2,2.4$ and $3.6 \mathrm{mg} / \mathrm{kg} /$ day in males. In total 4 groups were used, each consisting of 5 males and 5 females. In addition, 5 animals/sex/group were included in Groups 2-4 for toxicokinetic blood sampling. The following observations and examinations were evaluated: mortality, clinical signs (daily), body weight (twice weekly), food consumption (twice weekly) and water consumption (daily). Clinical pathology was performed on Day 8 (urinalysis only) and prior to necropsy, and a macroscopic examination and organ weight determination were performed at termination on Day 15. Blood was sampled for toxicokinetic evaluation on Days 1 and 14.

Dogs: PQR514 (4), formulated in 20\% (w/v) Hydroxypropyl-ß-cyclodextrin (HPßCD), was administered by oral gavage for 14 consecutive days to Beagle dogs at dose levels of $0,1,4$ and 10 $\mathrm{mg} / \mathrm{kg} /$ day. In total 4 groups were used, each consisting of 1 male and 1 female. The following observations and examinations were evaluated: clinical signs (daily), body weight (twice weekly), food consumption (daily), clinical pathology (haematology, biochemistry and urinalysis at pretest, Day 8 (urinalysis only) and at the end of the treatment period), and macroscopy at termination. Blood was sampled for toxicokinetic evaluation (Days 1 and 14). 
Table S1. Compiled Activity Data and Standard Errors (SEM).

\begin{tabular}{|c|c|c|c|c|}
\hline \multirow[b]{2}{*}{ Compound } & \multicolumn{4}{|c|}{$\log _{10}\left(\mathrm{IC}_{50},[\mathrm{nM}]\right)$} \\
\hline & $\begin{array}{c}\text { pPKB S473 } \\
\pm \text { SEM }\end{array}$ & $\begin{array}{c}\mathbf{p S 6 ~ S 2 3 5 / 2 3 6} \\
\pm \text { SEM }\end{array}$ & $\begin{array}{l}\text { p110a } \\
\pm \text { SEM } \\
\end{array}$ & $\begin{array}{l}\text { mTOR } \\
\pm \text { SEM }\end{array}$ \\
\hline PQR514 (4) & $\begin{array}{c}1.219 \\
\pm 0.04052 \\
\end{array}$ & $\begin{array}{c}1 \mathbf{1 . 7 8 4} \\
\pm 0.03964 \\
\end{array}$ & $\begin{aligned} & \mathbf{1 . 3 4 1} \\
& \pm 0.01363 \\
&\end{aligned}$ & $\begin{array}{r}\mathbf{1 . 6 9 8} \\
\pm 0.1352 \\
\end{array}$ \\
\hline 6 & $\begin{array}{c}1.807 \\
\pm 0.01798 \\
\end{array}$ & $\begin{array}{c}\mathbf{2 . 0 6 5} \\
\pm 0.01564 \\
\end{array}$ & $\begin{array}{c}\mathbf{1 . 4 1 7} \\
\pm 0.02826 \\
\end{array}$ & $\begin{array}{c}\mathbf{1 . 5 1 1} \\
\pm 0.1107 \\
\end{array}$ \\
\hline 7 & $\begin{aligned} & \mathbf{1 . 8 6 5} \\
\pm & 0.02616\end{aligned}$ & $\begin{array}{c}\mathbf{1 . 9 6} \\
+0.025\end{array}$ & $\begin{array}{l}\mathbf{1 . 5 1 9} \pm \\
0.03301\end{array}$ & $\begin{array}{l}\mathbf{1 . 3 2 8} \pm \\
0.1398\end{array}$ \\
\hline 8 & $\begin{aligned} & \mathbf{1 . 9 2 4} \\
\pm & 0.01528\end{aligned}$ & $\begin{array}{c}\mathbf{2 . 1 4 4} \\
\pm 0.0191\end{array}$ & $\begin{array}{c}\mathbf{1 . 6 2 5} \\
\pm 0.01609\end{array}$ & $\begin{array}{c}\mathbf{1 . 6 2 5} \\
\pm 0.1437\end{array}$ \\
\hline
\end{tabular}

Cellular $\mathrm{IC}_{50}$ s were calculated from two inhibition curves (each with 7 data points). $K_{\mathrm{i}}$ values were calculated from IC $\mathrm{C}_{50}$ s derived from two displacement curves (10 inhibitor concentrations each) using the following formula explained in detail in Ref. 10: $K_{\mathrm{i}}=\mathrm{IC}_{50} /\left(1+[\right.$ Tracer $] / \mathrm{K}_{\mathrm{d}}$ of Tracer). Values for compound $\mathbf{5}$ are reported in Ref. 16.

Table S2. Lipid Kinases and mTOR Binding Constants of PQR514 (4) and PQR309 (1)

\begin{tabular}{cccccc}
\cline { 2 - 6 } & \multicolumn{5}{c}{ Inhibitor binding constants ${ }^{\mathrm{a}} K_{\mathrm{d}},[\mathrm{nM}]$} \\
\hline Kinase $\rightarrow$ & PI3K $\alpha$ & \multicolumn{1}{c}{ PI3K $\beta$} & PI3K $\delta$ & PI3K $\gamma$ & mTOR \\
\hline PQR309 (1) & $1.5 \pm 0.8$ & $10.6 \pm 2.1$ & $25.0 \pm 14.1$ & $25.0 \pm 1.4$ & $11.5 \pm 0.7$ \\
PQR514 (4) & $2.0 \pm 0.4$ & $2.0 \pm 0.3$ & $3.4 \pm 0.07$ & $7.1 \pm 0.8$ & $21.5 \pm 2.1$ \\
\hline
\end{tabular}

${ }^{\text {a}}$ Dissociation constants $\left(K_{\mathrm{d}}\right)$ were determined using ScanMax technology (DiscoveRx) with 11 point 3-fold serial dilutions of the indicated compounds. $K_{\mathrm{d}}$ is the mean value from experiments performed in duplicate and were calculated from standard dose response curves using the Hill equation. Standard errors are reported. ${ }^{b}$ Dissociation constants $\left(K_{\mathrm{d}}\right)$ of PQR309 (1) are reprinted from Ref. 11. 


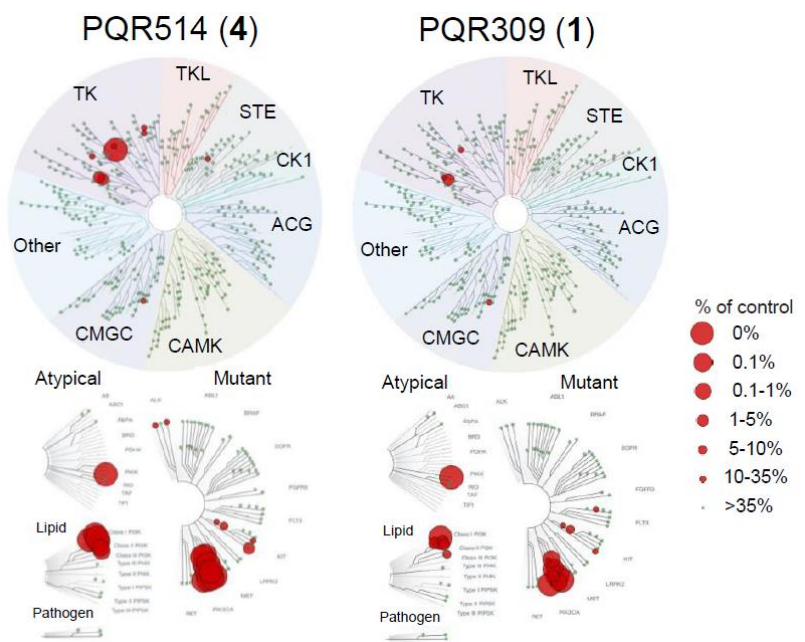

Figure S1. TREEspot ${ }^{\mathrm{TM}}$ Data Visualization of KINOMEScan Interactions of PQR514 (4) and PQR309 (1) at $10 \mu \mathrm{M}$.

Kinases are organized according to phylogeny and kinase families, which are: atypical kinases, lipid kinases, mutated kinases and some pathogen-derived kinases. Kinases targeted by indicated compounds are marked with red circles, where increasing circle size indicates a higher affinity of the inhibitor for the kinase. AGC: PKA, PKG and PKC kinases; CAMK: CalciumCalmodulin-dependent protein kinases; CK1: Casein kinase 1; CMGC: CDK, MAPK, GSK3, CLK family kinases; STE: Homologs of yeast Sterile 7, Sterile 11, Sterile 20 kinases; TK: Tyrosine kinases; TKL: Tyrosine kinase-like. The raw data used for the TREEspot ${ }^{\mathrm{TM}}$ representation is shown in Table S3. Values for PQR309 (1) are shown for comparison, and are from Ref. 11. 
Table S3. Kinase Interactions of PQR514 (4) and PQR309 (1) at $10 \mu \mathrm{M}$ (KINOMEscan $\left.{ }^{\mathrm{TM}}\right)$.

\begin{tabular}{|c|c|c|}
\hline \multirow{2}{*}{ KINOMEscan Gene Symbol } & PQR514 (4) & PQR309 (1) \\
\hline & $\%$ & $\%$ \\
\hline AAK1 & 62 & 83 \\
\hline ABL1(E255K)-phosphorylated & 79 & 83 \\
\hline ABL1(F317I)-nonphosphorylated & 84 & 100 \\
\hline ABL1(F317I)-phosphorylated & 70 & 100 \\
\hline ABL1(F317L)-nonphosphorylated & 81 & 100 \\
\hline ABL1(F317L)-phosphorylated & 86 & 66 \\
\hline ABL1(H396P)-nonphosphorylated & 60 & 92 \\
\hline ABL1(H396P)-phosphorylated & 60 & 96 \\
\hline ABL1(M351T)-phosphorylated & 68 & 100 \\
\hline ABL1(Q252H)-nonphosphorylated & 70 & 89 \\
\hline ABL1(Q252H)-phosphorylated & 47 & 88 \\
\hline ABL1(T315I)-nonphosphorylated & 89 & 100 \\
\hline ABL1(T315I)-phosphorylated & 64 & 80 \\
\hline ABL1(Y253F)-phosphorylated & 63 & 100 \\
\hline ABL1-nonphosphorylated & 70 & 62 \\
\hline ABL1-phosphorylated & 61 & 86 \\
\hline ABL2 & 99 & 95 \\
\hline ACVR1 & 83 & 77 \\
\hline ACVR1B & 94 & 99 \\
\hline ACVR2A & 100 & 89 \\
\hline ACVR2B & 100 & 76 \\
\hline ACVRL1 & 73 & 89 \\
\hline ADCK3 & 68 & 80 \\
\hline ADCK4 & 92 & 99 \\
\hline AKT1 & 94 & 75 \\
\hline AKT2 & 100 & 92 \\
\hline AKT3 & 59 & 97 \\
\hline ALK & 26 & 94 \\
\hline ALK(C1156Y) & 32 & 95 \\
\hline ALK(L1196M) & 44 & 95 \\
\hline AMPK-alpha1 & 91 & 78 \\
\hline AMPK-alpha2 & 91 & 100 \\
\hline ANKK1 & 54 & 79 \\
\hline ARK5 & 94 & 97 \\
\hline ASK1 & 92 & 55 \\
\hline ASK2 & 76 & 100 \\
\hline AURKA & 52 & 37 \\
\hline AURKB & 91 & 81 \\
\hline AURKC & 91 & 80 \\
\hline
\end{tabular}




\begin{tabular}{|c|c|c|}
\hline \multirow{2}{*}{ KINOMEscan Gene Symbol } & PQR514 (4) & PQR309 (1) \\
\hline & $\%$ & $\%$ \\
\hline AXL & 91 & 86 \\
\hline BIKE & 91 & 87 \\
\hline BLK & 70 & 61 \\
\hline BMPR1A & 93 & 100 \\
\hline BMPR1B & 72 & 67 \\
\hline BMPR2 & 81 & 82 \\
\hline BMX & 86 & 100 \\
\hline BRAF & 36 & 75 \\
\hline BRAF(V600E) & 42 & 65 \\
\hline BRK & 97 & 100 \\
\hline BRSK1 & 91 & 98 \\
\hline BRSK2 & 92 & 61 \\
\hline BTK & 26 & 83 \\
\hline BUB1 & 99 & 100 \\
\hline CAMK1 & 82 & 76 \\
\hline CAMK1D & 100 & 83 \\
\hline CAMK1G & 65 & 93 \\
\hline CAMK2A & 64 & 88 \\
\hline CAMK2B & 69 & 92 \\
\hline CAMK2D & 66 & 100 \\
\hline CAMK2G & 73 & 84 \\
\hline CAMK4 & 66 & 84 \\
\hline CAMKK1 & 70 & 100 \\
\hline CAMKK2 & 65 & 100 \\
\hline CASK & 77 & 100 \\
\hline CDC2L1 & 95 & 100 \\
\hline CDC2L2 & 89 & 100 \\
\hline CDC2L5 & 95 & 80 \\
\hline CDK11 & 69 & 70 \\
\hline CDK2 & 100 & 93 \\
\hline CDK3 & 88 & 99 \\
\hline CDK4-cyclinD1 & 100 & 91 \\
\hline CDK4-cyclinD3 & 87 & 97 \\
\hline CDK5 & 100 & 85 \\
\hline CDK7 & 56 & 100 \\
\hline CDK8 & 100 & 100 \\
\hline CDK9 & 99 & 70 \\
\hline CDKL1 & 97 & 93 \\
\hline CDKL2 & 99 & 100 \\
\hline CDKL3 & 74 & 85 \\
\hline CDKL5 & 67 & 83 \\
\hline
\end{tabular}




\begin{tabular}{|c|c|c|}
\hline \multirow{2}{*}{ KINOMEscan Gene Symbol } & PQR514 (4) & PQR309 (1) \\
\hline & $\%$ & $\%$ \\
\hline CHEK1 & 67 & 84 \\
\hline CHEK2 & 75 & 100 \\
\hline CIT & 91 & 100 \\
\hline CLK1 & 58 & 55 \\
\hline CLK2 & 41 & 84 \\
\hline CLK3 & 90 & 100 \\
\hline CLK4 & 30 & 32 \\
\hline CSF1R & 14 & 7.4 \\
\hline CSF1R-autoinhibited & 2.1 & 2.8 \\
\hline CSK & 73 & 76 \\
\hline CSNK1A1 & 72 & 91 \\
\hline CSNK1A1L & 74 & 95 \\
\hline CSNK1D & 90 & 76 \\
\hline CSNK1E & 38 & 78 \\
\hline CSNK1G1 & 79 & 100 \\
\hline CSNK1G2 & 85 & 82 \\
\hline CSNK1G3 & 95 & 100 \\
\hline CSNK2A1 & 79 & 59 \\
\hline CSNK2A2 & 69 & 100 \\
\hline CTK & 100 & 91 \\
\hline DAPK1 & 94 & 86 \\
\hline DAPK2 & 76 & 94 \\
\hline DAPK3 & 80 & 94 \\
\hline DCAMKL1 & 86 & 84 \\
\hline DCAMKL2 & 86 & 100 \\
\hline DCAMKL3 & 73 & 85 \\
\hline DDR1 & 69 & 65 \\
\hline DDR2 & 57 & 100 \\
\hline DLK & 91 & 81 \\
\hline DMPK & 76 & 100 \\
\hline DMPK2 & 77 & 81 \\
\hline DRAK1 & 89 & 97 \\
\hline DRAK2 & 85 & 79 \\
\hline DYRK1A & 48 & 100 \\
\hline DYRK1B & 76 & 61 \\
\hline DYRK2 & 82 & 100 \\
\hline EGFR & 56 & 73 \\
\hline EGFR(E746-A750del) & 77 & 95 \\
\hline EGFR(G719C) & 56 & 54 \\
\hline EGFR(G719S) & 75 & 64 \\
\hline EGFR(L747-E749del, A750P) & 63 & 85 \\
\hline
\end{tabular}




\begin{tabular}{|c|c|c|}
\hline \multirow{2}{*}{ KINOMEscan Gene Symbol } & PQR514 (4) & PQR309 (1) \\
\hline & $\%$ & $\%$ \\
\hline EGFR(L747-S752del, P753S) & 85 & 90 \\
\hline EGFR(L747-T751del,Sins) & 77 & 84 \\
\hline EGFR(L858R) & 40 & 90 \\
\hline EGFR(L858R,T790M) & 74 & 78 \\
\hline EGFR(L861Q) & 77 & 63 \\
\hline EGFR(S752-I759del) & 88 & 73 \\
\hline EGFR(T790M) & 51 & 92 \\
\hline EIF2AK1 & 85 & 100 \\
\hline EPHA1 & 68 & 76 \\
\hline EPHA2 & 94 & 100 \\
\hline EPHA3 & 69 & 79 \\
\hline EPHA4 & 94 & 83 \\
\hline EPHA5 & 97 & 98 \\
\hline EPHA6 & 94 & 89 \\
\hline EPHA7 & 86 & 93 \\
\hline EPHA8 & 100 & 80 \\
\hline EPHB1 & 98 & 70 \\
\hline EPHB2 & 95 & 95 \\
\hline EPHB3 & 96 & 84 \\
\hline EPHB4 & 97 & 84 \\
\hline EPHB6 & 50 & 54 \\
\hline ERBB2 & 65 & 65 \\
\hline ERBB3 & 69 & 61 \\
\hline ERBB4 & 60 & 79 \\
\hline ERK1 & 89 & 77 \\
\hline ERK2 & 98 & 89 \\
\hline ERK3 & 88 & 78 \\
\hline ERK4 & 99 & 100 \\
\hline ERK5 & 97 & 86 \\
\hline ERK8 & 100 & 100 \\
\hline ERN1 & 80 & 73 \\
\hline FAK & 100 & 79 \\
\hline FER & 67 & 96 \\
\hline FES & 91 & 76 \\
\hline FGFR1 & 94 & 100 \\
\hline FGFR2 & 90 & 93 \\
\hline FGFR3 & 88 & 100 \\
\hline FGFR3(G697C) & 83 & 65 \\
\hline FGFR4 & 100 & 84 \\
\hline FGR & 97 & 86 \\
\hline FLT1 & 91 & 98 \\
\hline
\end{tabular}




\begin{tabular}{|c|c|c|}
\hline \multirow{2}{*}{ KINOMEscan Gene Symbol } & PQR514 (4) & PQR309 (1) \\
\hline & $\%$ & $\%$ \\
\hline FLT3 & 88 & 52 \\
\hline FLT3(D835H) & 55 & 57 \\
\hline FLT3(D835Y) & 48 & 54 \\
\hline FLT3(ITD) & 77 & 90 \\
\hline FLT3(K663Q) & 48 & 69 \\
\hline FLT3(N841I) & 46 & 35 \\
\hline FLT3(R834Q) & 95 & 87 \\
\hline FLT3-autoinhibited & 50 & 78 \\
\hline FLT4 & 77 & 83 \\
\hline FRK & 100 & 100 \\
\hline FYN & 100 & 100 \\
\hline GAK & 75 & 97 \\
\hline GCN2(Kin.Dom.2,S808G) & 71 & 100 \\
\hline GRK1 & 86 & 100 \\
\hline GRK4 & 74 & 91 \\
\hline GRK7 & 67 & 100 \\
\hline GSK3A & 91 & 61 \\
\hline GSK3B & 74 & 92 \\
\hline HASPIN & 71 & 70 \\
\hline HCK & 77 & 95 \\
\hline HIPK1 & 69 & 76 \\
\hline HIPK2 & 59 & 100 \\
\hline HIPK3 & 56 & 78 \\
\hline HIPK4 & 100 & 86 \\
\hline HPK1 & 88 & 66 \\
\hline HUNK & 78 & 100 \\
\hline ICK & 72 & 100 \\
\hline IGF1R & 78 & 67 \\
\hline IKK-alpha & 39 & 100 \\
\hline IKK-beta & 77 & 100 \\
\hline IKK-epsilon & 99 & 100 \\
\hline INSR & 50 & 86 \\
\hline INSRR & 80 & 92 \\
\hline IRAK1 & 50 & 100 \\
\hline IRAK3 & 83 & 68 \\
\hline IRAK4 & 72 & 100 \\
\hline ITK & 44 & 88 \\
\hline JAK1(JH1domain-catalytic) & 90 & 80 \\
\hline JAK1(JH2domain-pseudokinase) & 0.05 & 20 \\
\hline JAK2(JH1domain-catalytic) & 65 & 88 \\
\hline JAK3(JH1domain-catalytic) & 46 & 63 \\
\hline
\end{tabular}




\begin{tabular}{|c|c|c|}
\hline \multirow{2}{*}{ KINOMEscan Gene Symbol } & PQR514 (4) & PQR309 (1) \\
\hline & $\%$ & $\%$ \\
\hline JNK1 & 86 & 74 \\
\hline JNK2 & 83 & 89 \\
\hline JNK3 & 90 & 83 \\
\hline KIT & 20 & 29 \\
\hline KIT(A829P) & 80 & 85 \\
\hline KIT(D816H) & 89 & 81 \\
\hline KIT(D816V) & 58 & 94 \\
\hline KIT(L576P) & 7.4 & 6.5 \\
\hline KIT(V559D) & 18 & 21 \\
\hline KIT(V559D,T670I) & 26 & 64 \\
\hline KIT(V559D,V654A) & 43 & 45 \\
\hline KIT-autoinhibited & 4.8 & 17 \\
\hline LATS1 & 82 & 96 \\
\hline LATS2 & 89 & 100 \\
\hline LCK & 46 & 93 \\
\hline LIMK1 & 86 & 97 \\
\hline LIMK2 & 81 & 62 \\
\hline LKB1 & 91 & 92 \\
\hline LOK & 64 & 72 \\
\hline LRRK2 & 97 & 91 \\
\hline LRRK2(G2019S) & 91 & 80 \\
\hline LTK & 26 & 86 \\
\hline LYN & 95 & 85 \\
\hline LZK & 100 & 97 \\
\hline MAK & 100 & 79 \\
\hline MAP3K1 & 77 & 100 \\
\hline MAP3K15 & 61 & 100 \\
\hline MAP3K2 & 71 & 100 \\
\hline MAP3K3 & 72 & 79 \\
\hline MAP3K4 & 82 & 68 \\
\hline MAP4K2 & 78 & 90 \\
\hline MAP4K3 & 87 & 71 \\
\hline MAP4K4 & 100 & 99 \\
\hline MAP4K5 & 100 & 89 \\
\hline MAPKAPK2 & 85 & 80 \\
\hline MAPKAPK5 & 72 & 89 \\
\hline MARK1 & 88 & 75 \\
\hline MARK2 & 77 & 87 \\
\hline MARK3 & 100 & 78 \\
\hline MARK4 & 90 & 76 \\
\hline MAST1 & 90 & 100 \\
\hline
\end{tabular}




\begin{tabular}{|c|c|c|}
\hline \multirow{2}{*}{ KINOMEscan Gene Symbol } & PQR514 (4) & PQR309 (1) \\
\hline & $\%$ & $\%$ \\
\hline MEK1 & 83 & 72 \\
\hline MEK2 & 77 & 98 \\
\hline MEK3 & 78 & 100 \\
\hline MEK4 & 96 & 100 \\
\hline MEK5 & 39 & 100 \\
\hline MEK6 & 92 & 70 \\
\hline MELK & 82 & 64 \\
\hline MERTK & 87 & 100 \\
\hline MET & 63 & 60 \\
\hline MET(M1250T) & 100 & 93 \\
\hline MET(Y1235D) & 92 & 100 \\
\hline MINK & 66 & 86 \\
\hline MKK7 & 61 & 100 \\
\hline MKNK1 & 45 & 100 \\
\hline MKNK2 & 56 & 91 \\
\hline MLCK & 84 & 94 \\
\hline MLK1 & 42 & 87 \\
\hline MLK2 & 53 & 59 \\
\hline MLK3 & 47 & 100 \\
\hline MRCKA & 95 & 100 \\
\hline MRCKB & 95 & 89 \\
\hline MST1 & 86 & 83 \\
\hline MST1R & 96 & 69 \\
\hline MST2 & 95 & 72 \\
\hline MST3 & 91 & 92 \\
\hline MST4 & 91 & 56 \\
\hline MTOR & 0 & 0 \\
\hline MUSK & 92 & 100 \\
\hline MYLK & 78 & 95 \\
\hline MYLK2 & 92 & 97 \\
\hline MYLK4 & 87 & 77 \\
\hline MYO3A & 92 & 86 \\
\hline MYO3B & 99 & 100 \\
\hline NDR1 & 66 & 71 \\
\hline NDR2 & 72 & 93 \\
\hline NEK1 & 99 & 76 \\
\hline NEK10 & 66 & 100 \\
\hline NEK11 & 89 & 100 \\
\hline NEK2 & 87 & 100 \\
\hline NEK3 & 78 & 100 \\
\hline NEK4 & 75 & 100 \\
\hline
\end{tabular}




\begin{tabular}{|c|c|c|}
\hline \multirow{2}{*}{ KINOMEscan Gene Symbol } & PQR514 (4) & PQR309 (1) \\
\hline & $\%$ & $\%$ \\
\hline NEK5 & 92 & 100 \\
\hline NEK6 & 100 & 100 \\
\hline NEK7 & 70 & 100 \\
\hline NEK9 & 92 & 100 \\
\hline NIK & 70 & 100 \\
\hline NIM1 & 68 & 92 \\
\hline NLK & 88 & 99 \\
\hline OSR1 & 54 & 100 \\
\hline p38-alpha & 82 & 98 \\
\hline p38-beta & 98 & 95 \\
\hline p38-delta & 95 & 55 \\
\hline p38-gamma & 100 & 74 \\
\hline PAK1 & 63 & 94 \\
\hline PAK2 & 58 & 88 \\
\hline PAK3 & 82 & 86 \\
\hline PAK4 & 58 & 93 \\
\hline PAK6 & 79 & 83 \\
\hline PAK7 & 52 & 86 \\
\hline PCTK1 & 90 & 100 \\
\hline PCTK2 & 100 & 98 \\
\hline PCTK3 & 82 & 100 \\
\hline PDGFRA & 80 & 85 \\
\hline PDGFRB & 69 & 97 \\
\hline PDPK1 & 83 & 53 \\
\hline PFCDPK1(P.falciparum) & 57 & 100 \\
\hline PFPK5(P.falciparum) & 64 & 78 \\
\hline PFTAIRE2 & 94 & 100 \\
\hline PFTK1 & 82 & 93 \\
\hline PHKG1 & 94 & 91 \\
\hline PHKG2 & 67 & 89 \\
\hline PIK3C2B & 0.75 & 41 \\
\hline PIK3C2G & 0.75 & 7 \\
\hline PIK3CA & 0 & 0.1 \\
\hline PIK3CA(C420R) & 0 & 0 \\
\hline PIK3CA(E542K) & 0 & 0.2 \\
\hline PIK3CA(E545A) & 0 & 0.1 \\
\hline PIK3CA(E545K) & 0 & 0.2 \\
\hline PIK3CA(H1047L) & 0 & 14 \\
\hline PIK3CA(H1047Y) & 0 & 1.4 \\
\hline PIK3CA(I800L) & 0.05 & 0.4 \\
\hline PIK3CA(M1043I) & 0 & 13 \\
\hline
\end{tabular}




\begin{tabular}{|c|c|c|}
\hline \multirow{2}{*}{ KINOMEscan Gene Symbol } & PQR514 (4) & PQR309 (1) \\
\hline & $\%$ & $\%$ \\
\hline PIK3CA(Q546K) & 0 & 0.5 \\
\hline PIK3CB & 0 & 2.6 \\
\hline PIK3CD & 0 & 2.6 \\
\hline PIK3CG & 0 & 1 \\
\hline PIK4CB & 75 & 95 \\
\hline PIM1 & 96 & 85 \\
\hline PIM2 & 92 & 86 \\
\hline PIM3 & 89 & 78 \\
\hline PIP5K1A & 100 & 82 \\
\hline PIP5K1C & 100 & 100 \\
\hline PIP5K2B & 100 & 94 \\
\hline PIP5K2C & 84 & 96 \\
\hline PKAC-alpha & 85 & 67 \\
\hline PKAC-beta & 61 & 83 \\
\hline PKMYT1 & 98 & 66 \\
\hline PKN1 & 49 & 73 \\
\hline PKN2 & 100 & 100 \\
\hline PKNB(M.tuberculosis) & 66 & 100 \\
\hline PLK1 & 66 & 49 \\
\hline PLK2 & 73 & 65 \\
\hline PLK3 & 83 & 96 \\
\hline PLK4 & 69 & 81 \\
\hline PRKCD & 97 & 100 \\
\hline PRKCE & 96 & 42 \\
\hline PRKCH & 91 & 100 \\
\hline PRKCI & 95 & 92 \\
\hline PRKCQ & 37 & 100 \\
\hline PRKD1 & 80 & 100 \\
\hline PRKD2 & 99 & 90 \\
\hline PRKD3 & 67 & 85 \\
\hline PRKG1 & 79 & 100 \\
\hline PRKG2 & 90 & 92 \\
\hline PRKR & 91 & 72 \\
\hline PRKX & 90 & 75 \\
\hline PRP4 & 100 & 79 \\
\hline PYK2 & 70 & 100 \\
\hline QSK & 72 & 84 \\
\hline RAF1 & 98 & 92 \\
\hline RET & 100 & 80 \\
\hline RET(M918T) & 78 & 84 \\
\hline RET(V804L) & 88 & 86 \\
\hline
\end{tabular}




\begin{tabular}{|c|c|c|}
\hline \multirow{2}{*}{ KINOMEscan Gene Symbol } & PQR514 (4) & PQR309 (1) \\
\hline & $\%$ & $\%$ \\
\hline RET(V804M) & 73 & 86 \\
\hline RIOK1 & 82 & 97 \\
\hline RIOK2 & 51 & 90 \\
\hline RIOK3 & 98 & 84 \\
\hline RIPK1 & 91 & 84 \\
\hline RIPK2 & 100 & 100 \\
\hline RIPK4 & 82 & 100 \\
\hline RIPK5 & 79 & 98 \\
\hline ROCK1 & 99 & 100 \\
\hline ROCK2 & 100 & 100 \\
\hline ROS1 & 54 & 65 \\
\hline RPS6KA4(Kin.Dom.1-N-terminal) & 82 & 86 \\
\hline RPS6KA4(Kin.Dom.2-C-terminal) & 63 & 88 \\
\hline RPS6KA5(Kin.Dom.1-N-terminal) & 88 & 92 \\
\hline RPS6KA5(Kin.Dom.2-C-terminal) & 88 & 95 \\
\hline RSK1(Kin.Dom.1-N-terminal) & 75 & 74 \\
\hline RSK1(Kin.Dom.2-C-terminal) & 88 & 86 \\
\hline RSK2(Kin.Dom.1-N-terminal) & 59 & 96 \\
\hline RSK2(Kin.Dom.2-C-terminal) & 84 & 96 \\
\hline RSK3(Kin.Dom.1-N-terminal) & 44 & 100 \\
\hline RSK3(Kin.Dom.2-C-terminal) & 95 & 100 \\
\hline RSK4(Kin.Dom.1-N-terminal) & 48 & 100 \\
\hline RSK4(Kin.Dom.2-C-terminal) & 94 & 100 \\
\hline S6K1 & 76 & 100 \\
\hline SBK1 & 60 & 100 \\
\hline SGK & 77 & 93 \\
\hline SgK110 & 85 & 76 \\
\hline SGK2 & 84 & 96 \\
\hline SGK3 & 44 & 89 \\
\hline SIK & 100 & 91 \\
\hline SIK2 & 97 & 97 \\
\hline SLK & 24 & 96 \\
\hline SNARK & 50 & 100 \\
\hline SNRK & 81 & 100 \\
\hline SRC & 57 & 77 \\
\hline SRMS & 88 & 94 \\
\hline SRPK1 & 82 & 78 \\
\hline SRPK2 & 100 & 58 \\
\hline SRPK3 & 77 & 77 \\
\hline STK16 & 56 & 78 \\
\hline STK33 & 94 & 66 \\
\hline
\end{tabular}




\begin{tabular}{|c|c|c|}
\hline \multirow{2}{*}{ KINOMEscan Gene Symbol } & PQR514 (4) & PQR309 (1) \\
\hline & $\%$ & $\%$ \\
\hline STK35 & 55 & 85 \\
\hline STK36 & 99 & 86 \\
\hline STK39 & 70 & 100 \\
\hline SYK & 61 & 100 \\
\hline TAK1 & 91 & 100 \\
\hline TAOK1 & 60 & 86 \\
\hline TAOK2 & 92 & 100 \\
\hline TAOK3 & 70 & 87 \\
\hline TBK1 & 95 & 76 \\
\hline TEC & 58 & 80 \\
\hline TESK1 & 72 & 83 \\
\hline TGFBR1 & 100 & 100 \\
\hline TGFBR2 & 69 & 90 \\
\hline TIE1 & 84 & 100 \\
\hline TIE2 & 99 & 100 \\
\hline TLK1 & 92 & 93 \\
\hline TLK2 & 100 & 74 \\
\hline TNIK & 82 & 75 \\
\hline TNK1 & 83 & 90 \\
\hline TNK2 & 85 & 75 \\
\hline TNNI3K & 100 & 100 \\
\hline TRKA & 78 & 88 \\
\hline TRKB & 74 & 84 \\
\hline TRKC & 87 & 92 \\
\hline TRPM6 & 59 & 85 \\
\hline TSSK1B & 100 & 90 \\
\hline TTK & 84 & 80 \\
\hline TXK & 56 & 74 \\
\hline TYK2(JH1domain-catalytic) & 56 & 91 \\
\hline TYK2(JH2domain-pseudokinase) & 15 & 100 \\
\hline TYRO3 & 81 & 68 \\
\hline ULK1 & 57 & 100 \\
\hline ULK2 & 72 & 91 \\
\hline ULK3 & 60 & 100 \\
\hline VEGFR2 & 41 & 100 \\
\hline VRK2 & 64 & 100 \\
\hline WEE1 & 100 & 84 \\
\hline WEE2 & 82 & 100 \\
\hline WNK1 & 57 & 100 \\
\hline WNK3 & 56 & 100 \\
\hline YANK1 & 94 & 100 \\
\hline
\end{tabular}




\begin{tabular}{|c|c|c|}
\hline \multirow{2}{*}{ KINOMEscan Gene Symbol } & PQR514 (4) & PQR309 (1) \\
\cline { 2 - 3 } & $\%$ & $\%$ \\
\hline YANK2 & 90 & 76 \\
\hline YANK3 & 100 & 79 \\
\hline YES & 80 & 76 \\
\hline YSK1 & 93 & 69 \\
\hline YSK4 & 41 & 100 \\
\hline ZAK & 80 & 83 \\
\hline ZAP70 & 94 & 87 \\
\hline
\end{tabular}

Previously determined values for PQR309 (1) are shown for comparison and are from Ref. 11.

Table S4. Selectivity Profile of PQR514 (4) Calculated from KinomeScan Data.

\begin{tabular}{cccccc}
\hline S-Score $^{\mathbf{a}}$ & S35 (\# of hits) & S10 (\# of hits) & S1(\# of hits) & \# of Kinases & Drug [nM] \\
\hline PQR514 (4) & $0.041(16)$ & $0.025(10)$ & $0.02(8)$ & 395 & 10000 \\
\hline
\end{tabular}

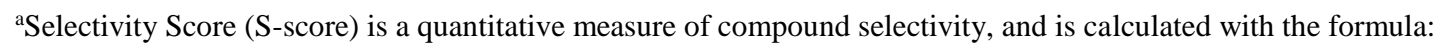

$\mathrm{S}=$ Number of hits / Number of tested kinases (excluding mutant variants).

$\mathrm{S} 35, \mathrm{~S} 10, \mathrm{~S} 1$ were calculated using $\% \mathrm{Ctrl}$ as a potency threshold $(35,10,1 \%)$, e.g. $\mathrm{S}(35)=$ (number of non-mutant kinases with \% Ctrl <35)/(number of non-mutant kinases tested). 
Table S5. In Vitro Pharmacology I - Ligand Binding Assays with PQR514 (4) at $10 \mu \mathrm{M}$.

\begin{tabular}{|c|c|}
\hline \multicolumn{2}{|c|}{ GPCRs, Ion channels, Nuclear Receptors and Transporters, [\% of control] } \\
\hline A2A* (aRL) & 93.3 \\
\hline$\alpha 1 A^{*}($ ant-RL) & 94.4 \\
\hline$\alpha 2 \mathrm{~A}^{*}($ ant-RL) & 113.9 \\
\hline$\beta 1^{*}(\mathrm{aRL})$ & 93.2 \\
\hline$\beta 2 *(\mathrm{aRL})$ & 98.0 \\
\hline BZD (central) (aRL) & 135.5 \\
\hline CB1*(aRL) & 96.5 \\
\hline $\mathrm{CB} 2 *(\mathrm{aRL})$ & 95.9 \\
\hline CCK1 (CCKA)* (aRL) & 118.4 \\
\hline D1* (ant-RL) & 90.9 \\
\hline D2S* (aRL) & 117.8 \\
\hline ETA* $^{*}(\mathrm{aRL})$ & 102.8 \\
\hline NMDA (ant-RL) & 99.6 \\
\hline $\mathrm{H} 1 *$ (ant-RL) & 99.1 \\
\hline $\mathrm{H} 2 *$ (ant-RL) & 105.7 \\
\hline MAO-A (ant-RL) & 95.4 \\
\hline M1* (ant-RL) & 110.6 \\
\hline M2* (ant-RL) & 117.4 \\
\hline M3* (ant-RL) & 115.6 \\
\hline $\mathrm{N}$ neuronal $\alpha 4 \beta 2 *(\mathrm{aRL})$ & 102.4 \\
\hline$\delta 2(\mathrm{DOP}) *(\mathrm{aRL})$ & 103.3 \\
\hline$\kappa(\mathrm{KOP})(\mathrm{aRL})$ & 113.8 \\
\hline$\mu(\mathrm{MOP})^{*}(\mathrm{aRL})$ & 103.8 \\
\hline 5-HT1A* (aRL) & 102.1 \\
\hline 5-HT1B (ant-RL) & 115.2 \\
\hline 5-HT2A*(aRL) & 98.1 \\
\hline $5-\mathrm{HT} 2 \mathrm{~B} *(\mathrm{aRL})$ & 94.1 \\
\hline 5-HT3* (ant-RL) & 100.3 \\
\hline GR* (aRL) & 104.9 \\
\hline $\mathrm{AR}^{*}(\mathrm{aRL})$ & 89.3 \\
\hline V1 a* (aRL) & 104.3 \\
\hline $\mathrm{Ca} 2+$ channel (L, dihydropyridine site) (ant-RL) & 98.5 \\
\hline hERG (membrane preparation) (ant-RL) & 115.9 \\
\hline KV channel (ant-RL) & 109.4 \\
\hline $\mathrm{Na}+$ channel (site 2$)($ ant-RL) & 103.5 \\
\hline norepinephrine transporter* (ant-RL) & 98.5 \\
\hline dopamine transporter* (ant-RL) & 95.0 \\
\hline 5-HT transporter* (ant-RL) & 94.0 \\
\hline
\end{tabular}

*human target; aRL: agonist radioligand; ant-RL: antagonist radioligand; For further information see BioPrint ${ }^{\circledR}$ Panel P22-p at eurofinsdiscoveryservices.com. 
Table S6. In Vitro Pharmacology II - Enzyme Assays with PQR514 (4) at $10 \mu \mathrm{M}$.

\begin{tabular}{|c|c|}
\hline Enzymes tested & \% of control \\
\hline COX1* & 95.0 \\
\hline COX2* & 99.0 \\
\hline PDE3A* & 39.1 \\
\hline PDE4D2* & 75.0 \\
\hline Lck kinase* & 92.0 \\
\hline acetylcholinesterase* & 98.0 \\
\hline
\end{tabular}


Table S7. Impact of PQR514 (4), PQR309 (1) and PQR530 (16) on cell proliferation.

\begin{tabular}{|c|c|c|c|}
\hline \multicolumn{4}{|c|}{ Half maximal growth inhibition, GI50 [nM] } \\
\hline Cell Lines & PQR514 (4) & PQR309 (1) & PQR530 (16) \\
\hline SHP-77 & 1773 & 6701 & 2124 \\
\hline COLO829 & 1147 & & 930 \\
\hline DLD-1 & 728 & 1326 & 538 \\
\hline K-562 & 715 & 2515 & 1058 \\
\hline SNU-C2B & 607 & & 728 \\
\hline $\mathrm{T} 24$ & 557 & & 593 \\
\hline MA PaCa-2 & 555 & & 885 \\
\hline KU812 & 520 & & 390 \\
\hline SW480 & 472 & 2574 & 713 \\
\hline Jurkat E6-1 & 465 & 720 & 1127 \\
\hline PA-1 & 412 & 612 & 694 \\
\hline A-172 & 355 & 1188 & 299 \\
\hline $786-\mathrm{O}$ & 340 & 2076 & 703 \\
\hline C-33 A & 334 & 1091 & 331 \\
\hline TT & 331 & & 576 \\
\hline COLO205 & 310 & & 642 \\
\hline AsPC-1 & 306 & & 468 \\
\hline RT4 & 305 & & 352 \\
\hline SW620 & 300 & 1774 & 665 \\
\hline $\mathrm{FaDu}$ & 288 & 1329 & 463 \\
\hline SUP-T1 & 276 & & 522 \\
\hline NCI-H82 & 276 & 911 & 504 \\
\hline A375 & 269 & 1153 & 469 \\
\hline 769-P & 267 & 1119 & 458 \\
\hline MeWo & 240 & 1043 & 329 \\
\hline $\mathrm{U}-2 \mathrm{OS}$ & 203 & 536 & 311 \\
\hline $\mathrm{U}-87 \mathrm{MG}$ & 194 & 1483 & 546 \\
\hline J82 & 191 & 988 & 477 \\
\hline CAL 27 & 189 & 1523 & 349 \\
\hline RKO & 180 & & 477 \\
\hline SR & 176 & 289 & 193 \\
\hline SK-N-AS & 172 & 927 & 402 \\
\hline HCT-15 & 161 & 713 & 402 \\
\hline BT-549 & 160 & 1324 & 329 \\
\hline LS 174T & 135 & 957 & 403 \\
\hline RPMI-7951 & 135 & 775 & 300 \\
\hline SK-N-FI & 130 & & 449 \\
\hline Daoy & 126 & & 366 \\
\hline SJCRH30 & 126 & 539 & 442 \\
\hline A-427 & 121 & 753 & 168 \\
\hline SW948 & 118 & & 347 \\
\hline T98G & 118 & & 350 \\
\hline
\end{tabular}




\begin{tabular}{|c|c|c|c|}
\hline HCT 116 & 114 & 1324 & 574 \\
\hline Hs 578T & 111 & 817 & 354 \\
\hline MG-63 & 109 & 535 & 241 \\
\hline A388 & 103 & & 202 \\
\hline A-549 & 102 & 624 & 250 \\
\hline $\mathrm{BxPC}-3$ & 97 & 414 & 347 \\
\hline CCRF-CEM & 92 & 849 & 160 \\
\hline DoTc2 4520 & 83 & & 420 \\
\hline MOLT-4 & 83 & 393 & 212 \\
\hline SW48 & 77 & 175 & 200 \\
\hline A-704 & 70 & & 361 \\
\hline NCI-H460 & 67 & 477 & 150 \\
\hline LNCaP FGC & 60 & & 356 \\
\hline DU 145 & 59 & & 237 \\
\hline $\mathrm{ACHN}$ & 54 & 369 & 231 \\
\hline VA-ES-BJ & 53 & & 127 \\
\hline AU-565 & 47 & 320 & 212 \\
\hline LoVo & 46 & 332 & 315 \\
\hline BT-20 & 42 & 509 & 183 \\
\hline AN3 CA & 42 & 293 & 126 \\
\hline A-498 & 41 & 530 & 128 \\
\hline OVCAR-3 & 34 & 229 & 118 \\
\hline MCF7 & 22 & & 97 \\
\hline A-204 & 22 & 102 & 129 \\
\hline Mean 66 cell lines & 249 & - & 433 \\
\hline Mean 44 cell lines & 236 & 1028 & 426 \\
\hline
\end{tabular}

NTRC, The Netherlands Translational Research Center cell panels were run with PQR514 (4) and PQR530 (16) [66 cell lines], and with PQR309 (1) [44 cell lines]. The dataset for PQR309 (1) is from Ref. 11, and for PQR530 (16) is from Ref. 16. 
Table S8. Physicochemical Properties of PQR514 (4).

\begin{tabular}{|c|c|c|c|c|c|c|c|}
\hline \multirow{2}{*}{$\begin{array}{l}\text { Permeability } \\
\text { Papp [nm/s] }\end{array}$} & \multicolumn{5}{|c|}{ Thermodynamic solubility, $[\mu \mathrm{M}]$} & \multirow[b]{2}{*}{$\operatorname{clog} \mathrm{P}^{\mathrm{c}}$} & \multirow{2}{*}{$\begin{array}{l}\text { Mol.wt. } \\
\text { [g/mol] }\end{array}$} \\
\hline & $\mathrm{pH} 1.2$ & $\mathrm{pH} 4.5$ & pH 6.8 & FaSSIF $^{\mathrm{a}}$ & FeSSIF $^{b}$ & & \\
\hline $81.96 \pm 5.40$ & $\begin{array}{l}34.5 \\
\pm 1.8\end{array}$ & $\begin{array}{l}3.8 \\
\pm 0.2\end{array}$ & $\begin{array}{l}3.75 \\
\pm 0.5\end{array}$ & $\begin{array}{l}7.6 \\
\pm 0.6\end{array}$ & $\begin{array}{l}13.9 \\
\pm 0.7\end{array}$ & 1. & 394.39 \\
\hline
\end{tabular}

aFaSSIF: Fasted Simulated Intestinal Fluid. ${ }^{b}$ FeSSIF: Fed Simulated Intestinal Fluid. ${ }^{c}$ clogP values were calculated using MarvinSketch ${ }^{\mathrm{TM}}$. Solubility assays were performed by Aphad Analytical Solutions. 
Table S9. Safety Profile of PQR514 (4).

\begin{tabular}{|c|c|}
\hline Studies & Results \\
\hline \multicolumn{2}{|r|}{ Toxicity tests in vivo } \\
\hline $\begin{array}{l}\text { 4-Day range finding and } \\
\text { 14-day pilot study by daily } \\
\text { oral gavage in Wistar rats } \\
\text { and Beagle dogs. }\end{array}$ & 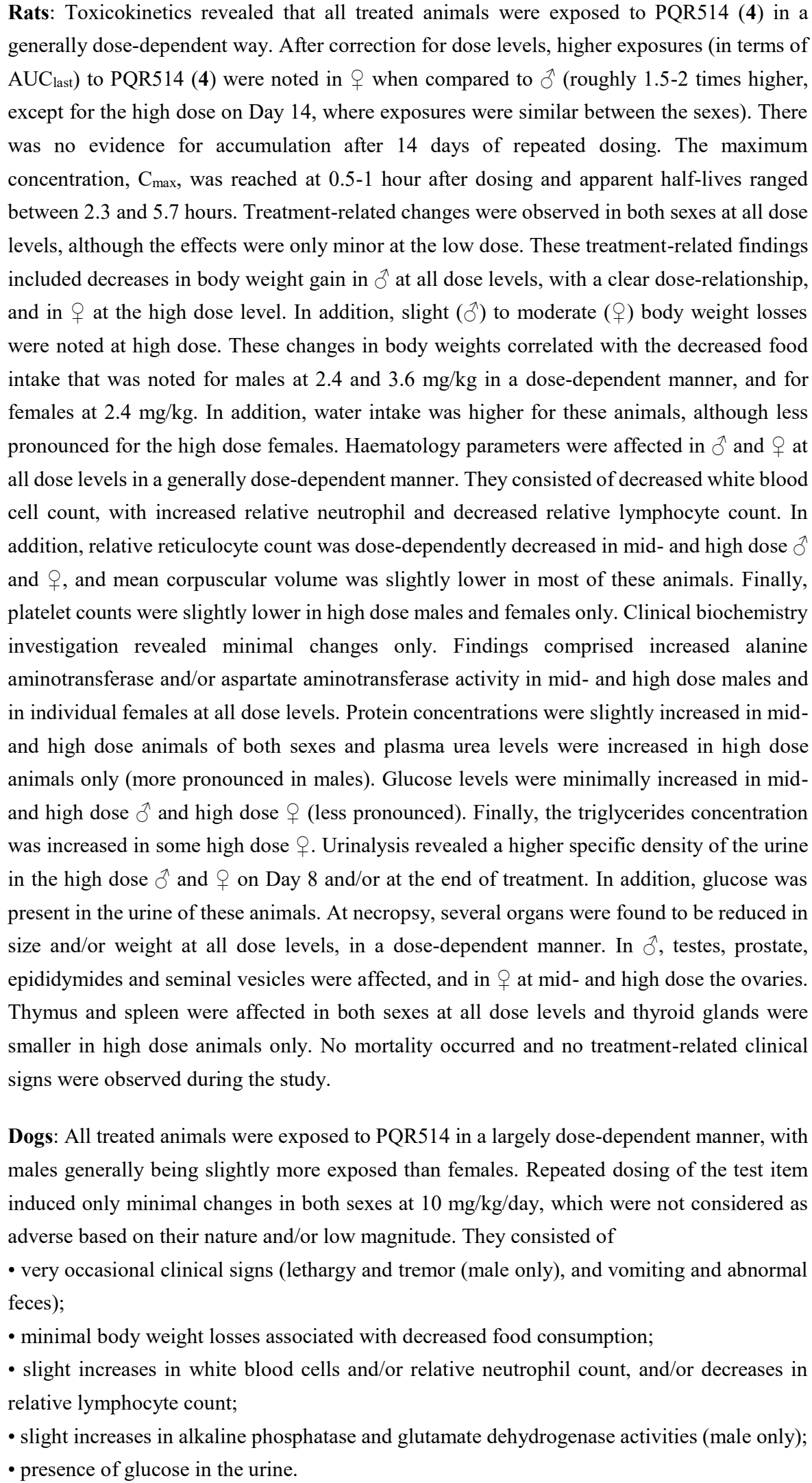 \\
\hline
\end{tabular}


1H NMR Spectra Final Compounds.

4-(difluoromethyl)-5-(4,6-dimorpholino-1,3,5-triazin-2-yl)pyrimidin-2-amine (PQR514, 4):

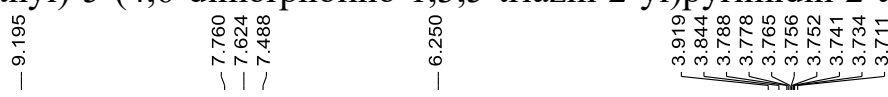

(1)
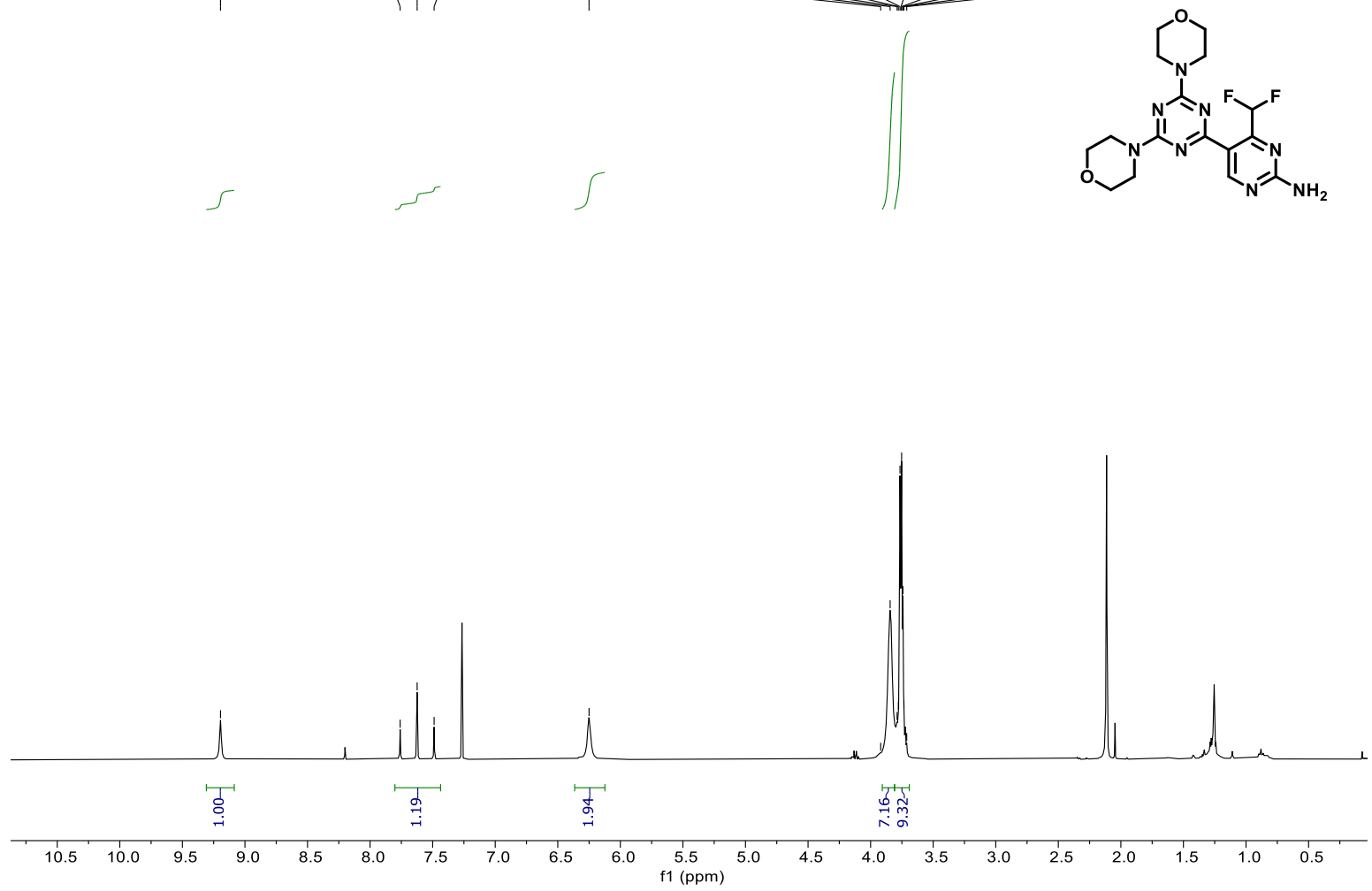

(R)-4-(difluoromethyl)-5-(4-(3-methylmorpholino)-6-morpholino-1,3,5-triazin-2-yl)pyrimidin-2amine (6):

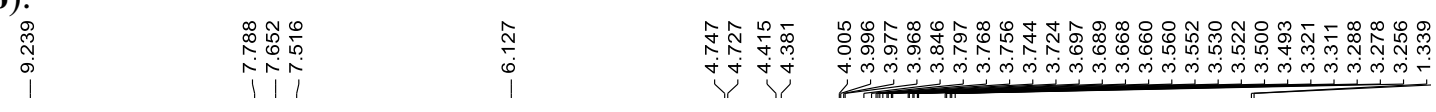

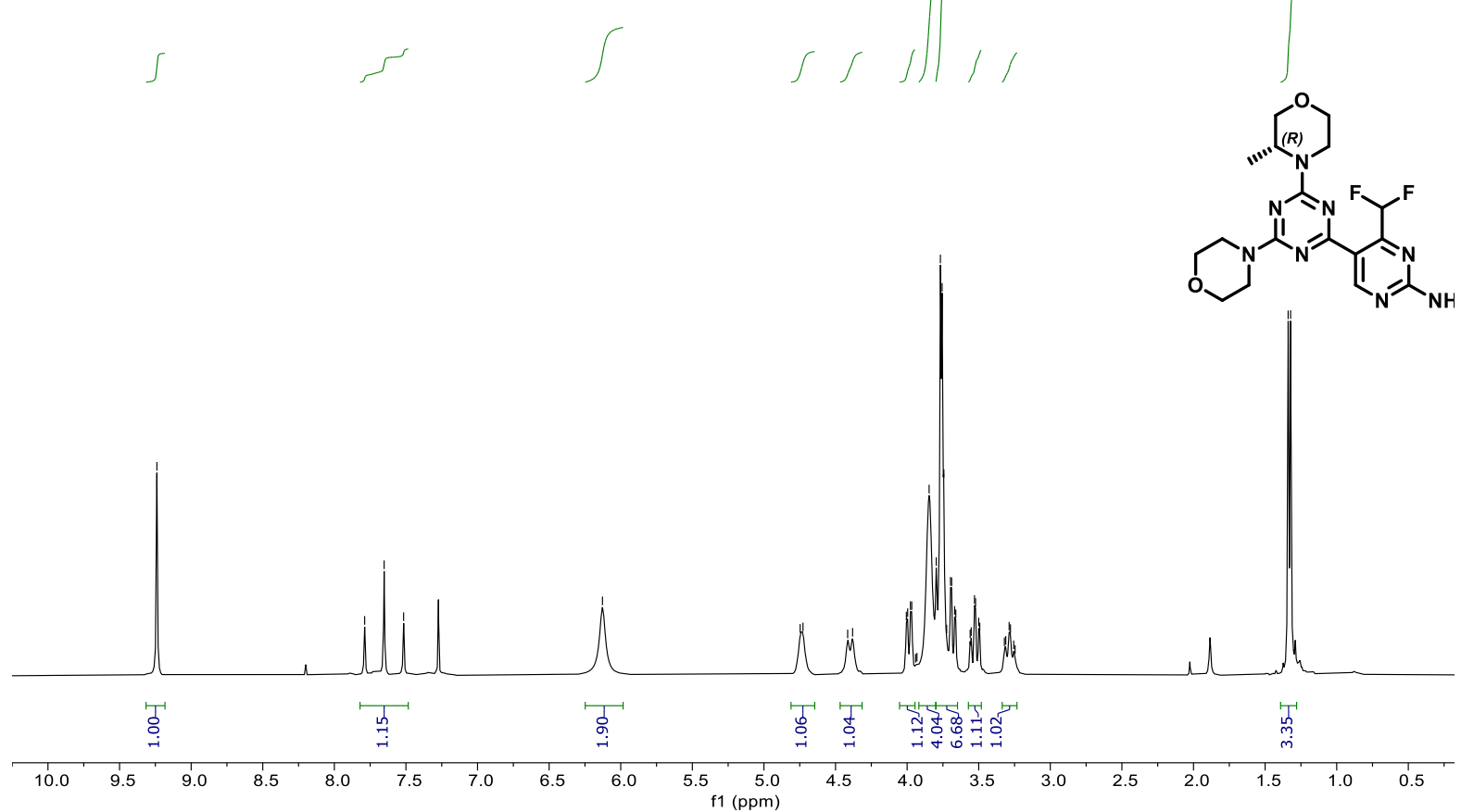


5-(4-((1R,5S)-3-oxa-8-azabicyclo[3.2.1]octan-8-yl)-6-morpholino-1,3,5-triazin-2-yl)-4(difluoromethyl)pyrimidin-2-amine (7):

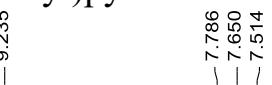

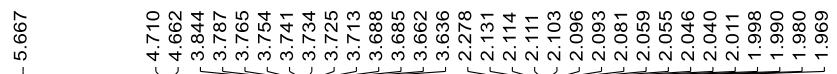

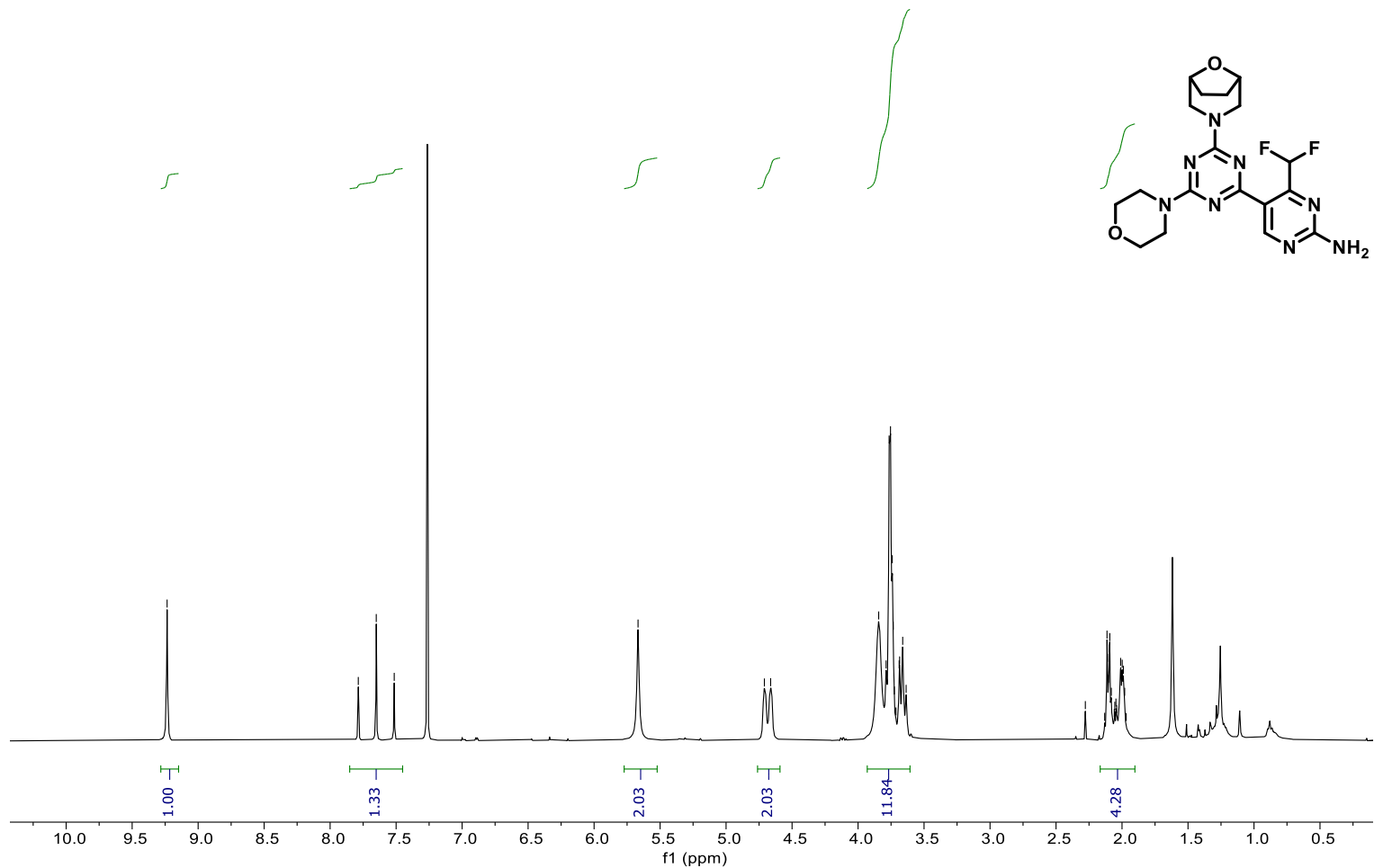

5-(4-((1R,5S)-8-oxa-3-azabicyclo[3.2.1]octan-3-yl)-6-morpholino-1,3,5-triazin-2-yl)-4(difluoromethyl)pyrimidin-2-amine (8):$$
\text { ว }
$$$$
\text { ili }
$$

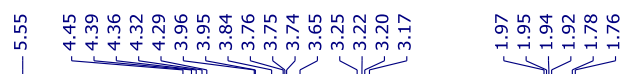

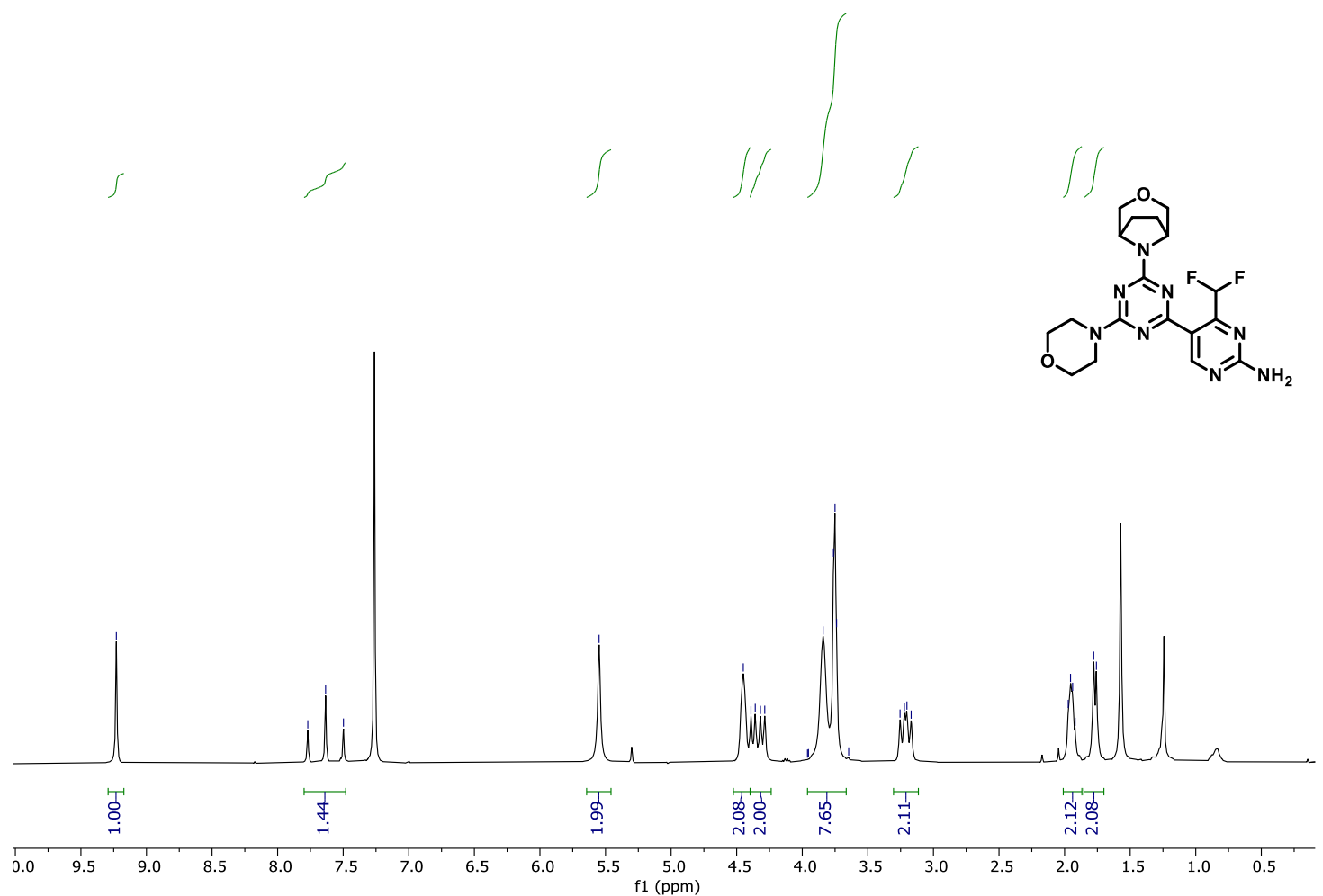


13C NMR Spectra Final Compounds.

4-(difluoromethyl)-5-(4,6-dimorpholino-1,3,5-triazin-2-yl)pyrimidin-2-amine (PQR514, 4):

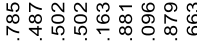

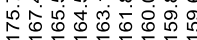

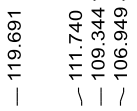

$\bar{c}$
$\substack{0 \\ 0 \\ 1}$

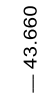
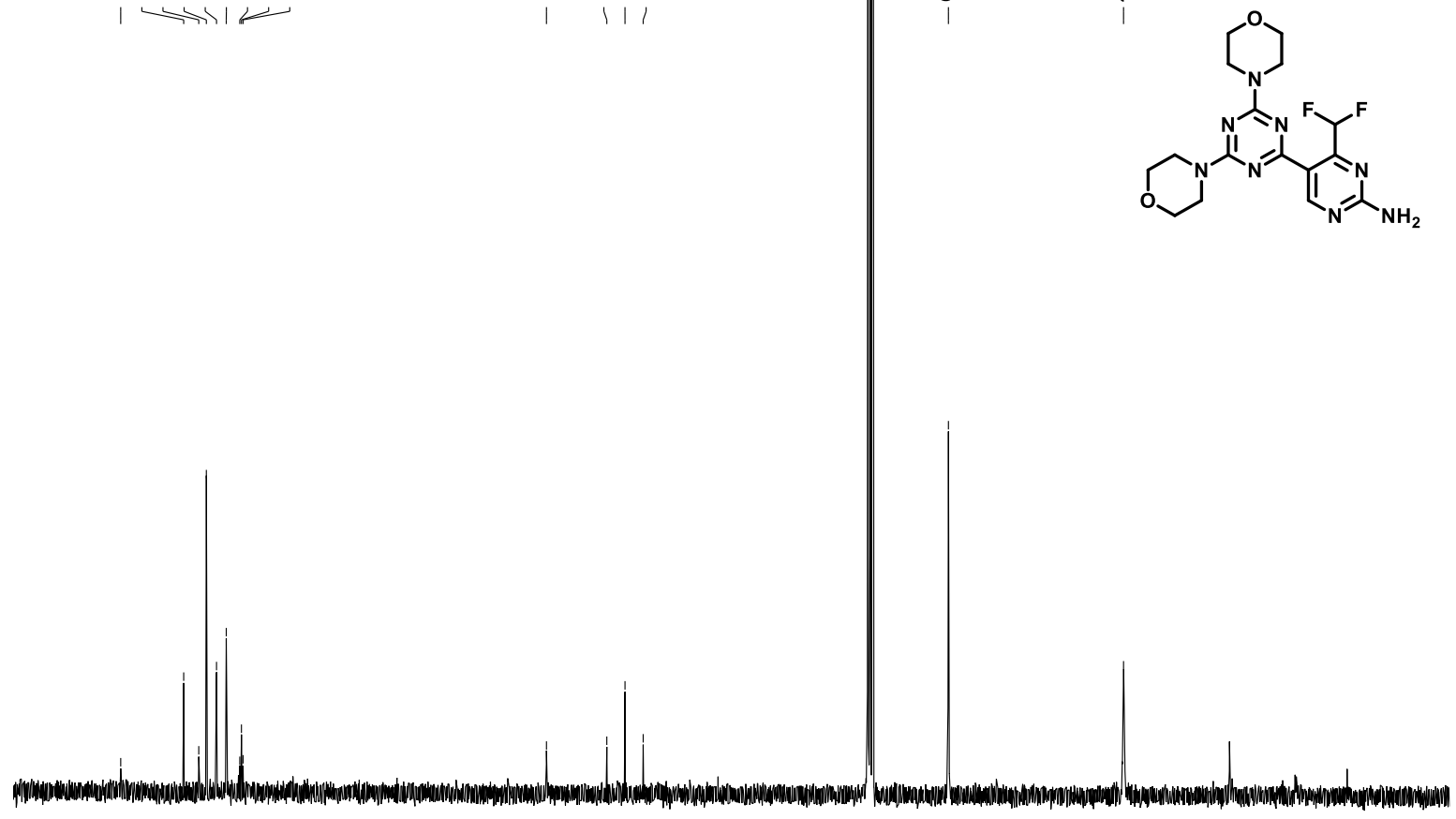

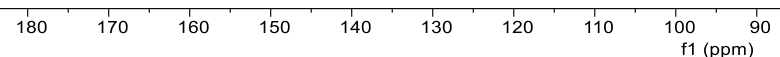

(R)-4-(difluoromethyl)-5-(4-(3-methylmorpholino)-6-morpholino-1,3,5-triazin-2-yl)pyrimidin-2amine (6):

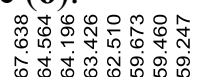

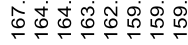

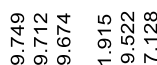

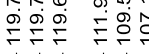

里是京

रंष्ठ

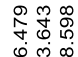

juj

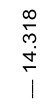
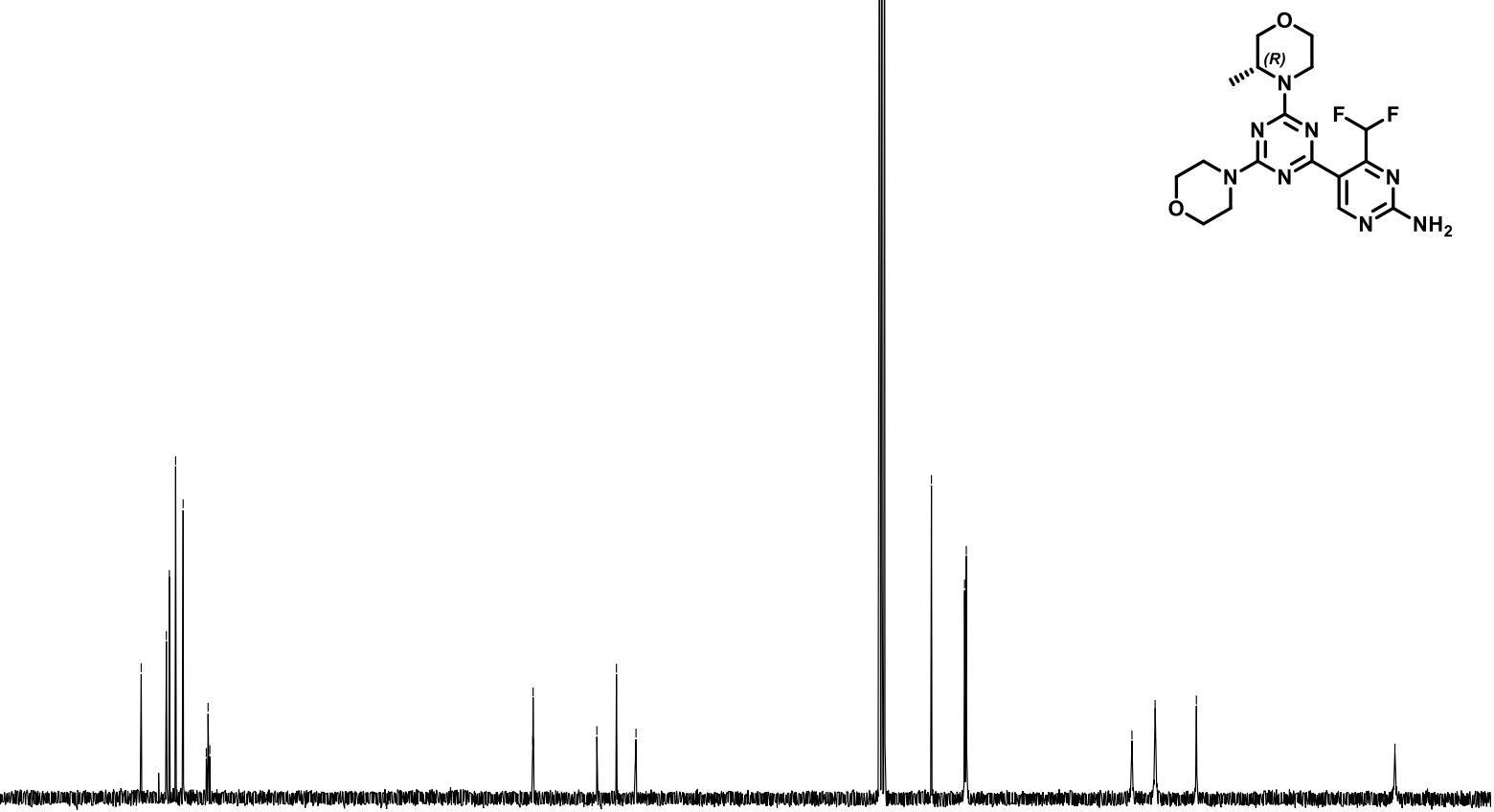
5-(4-((1R,5S)-3-oxa-8-azabicyclo[3.2.1]octan-8-yl)-6-morpholino-1,3,5-triazin-2-yl)-4(difluoromethyl)pyrimidin-2-amine (7):

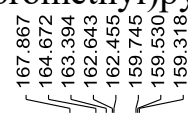

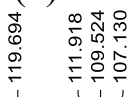

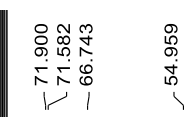

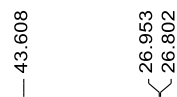
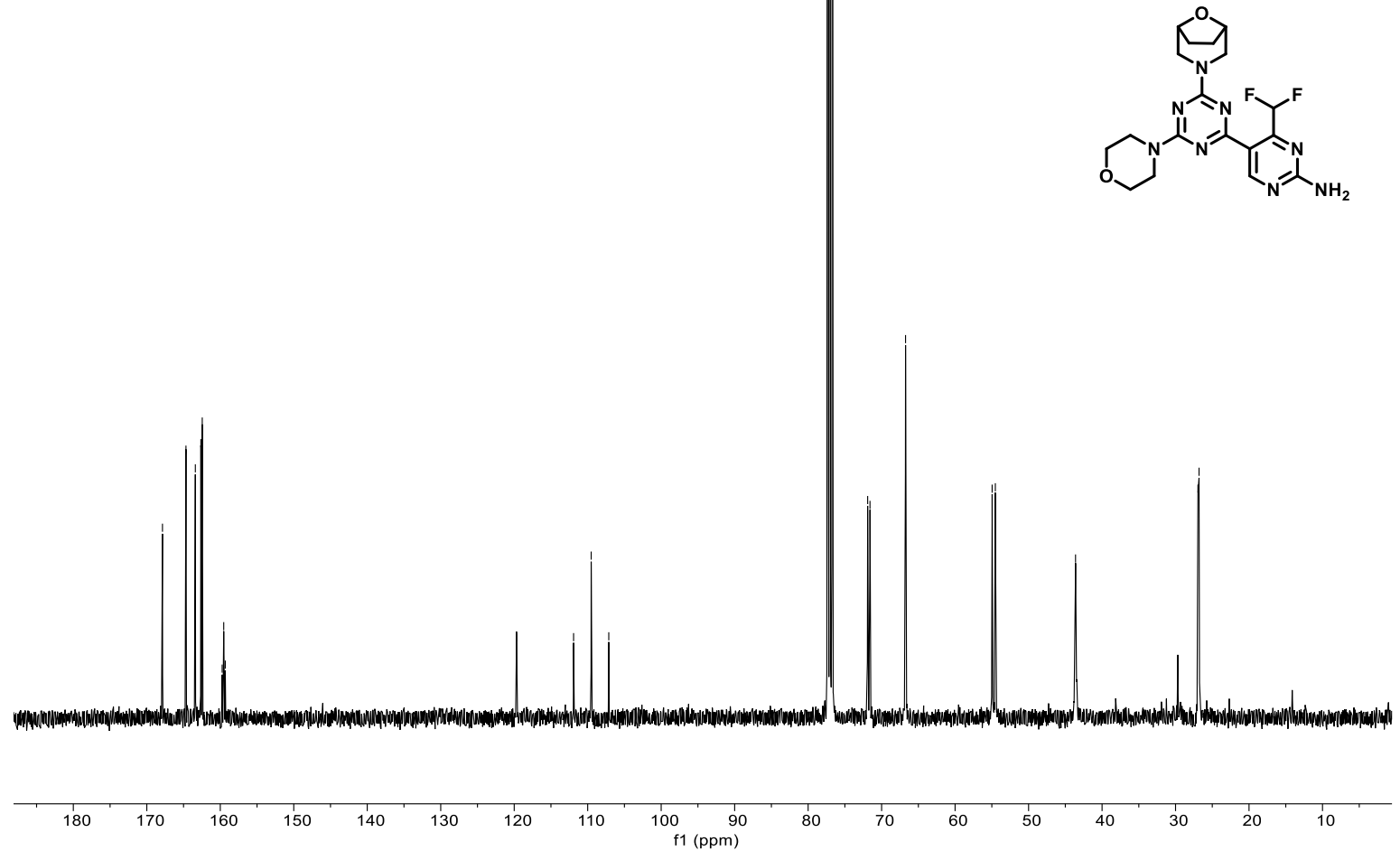

5-(4-((1R,5S)-8-oxa-3-azabicyclo[3.2.1]octan-3-yl)-6-morpholino-1,3,5-triazin-2-yl)-4(difluoromethyl)pyrimidin-2-amine (8):

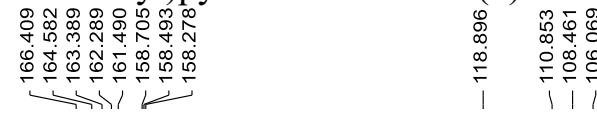

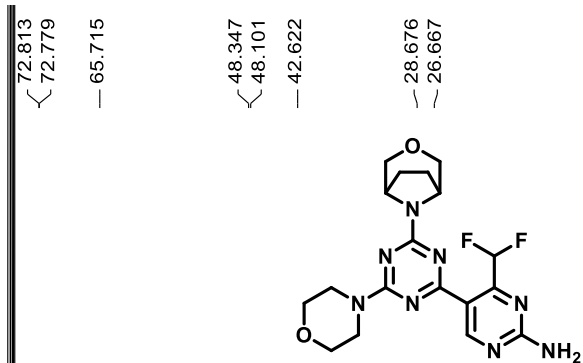

$180 \quad 170 \quad 160$

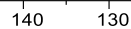

120

110

$100 \quad 90$

80

$70 \quad 60$

50

40

$20 \quad 10$ 
HRMS Spectra Final Compounds.

4-(difluoromethyl)-5-(4,6-dimorpholino-1,3,5-triazin-2-yl)pyrimidin-2-amine (PQR514, 4):

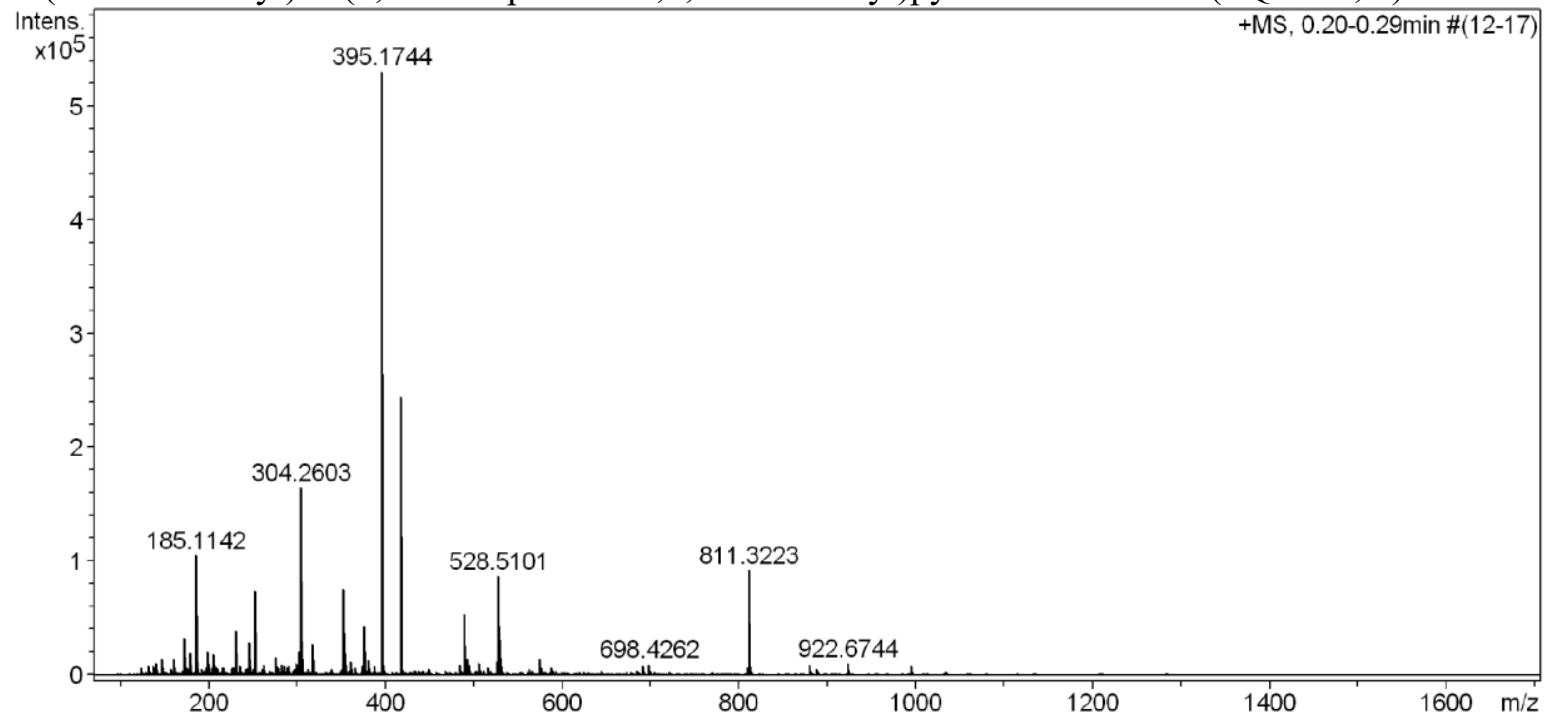

(R)-4-(difluoromethyl)-5-(4-(3-methylmorpholino)-6-morpholino-1,3,5-triazin-2-yl)pyrimidin-2amine (6):

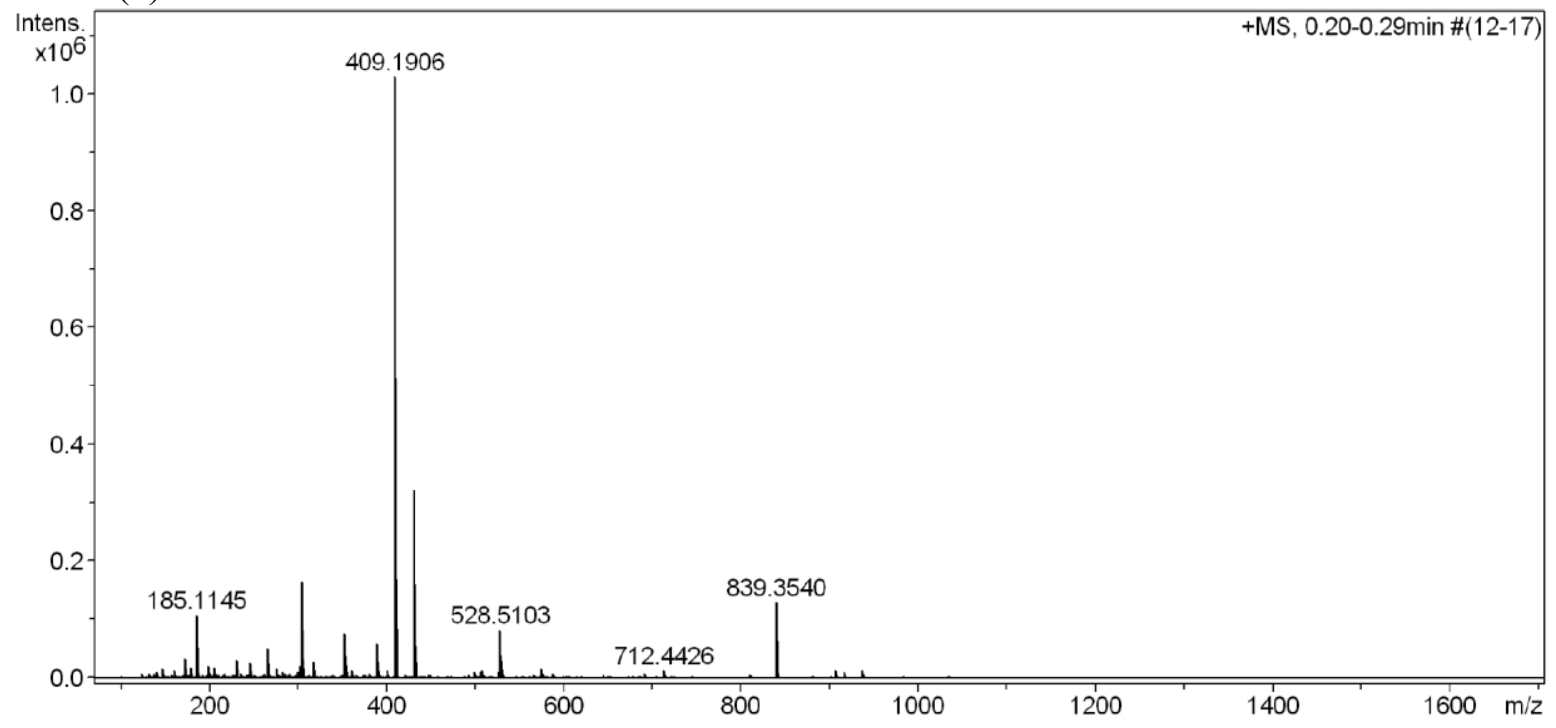


5-(4-((1R,5S)-3-oxa-8-azabicyclo[3.2.1]octan-8-yl)-6-morpholino-1,3,5-triazin-2-yl)-4(difluoromethyl)pyrimidin-2-amine (7):

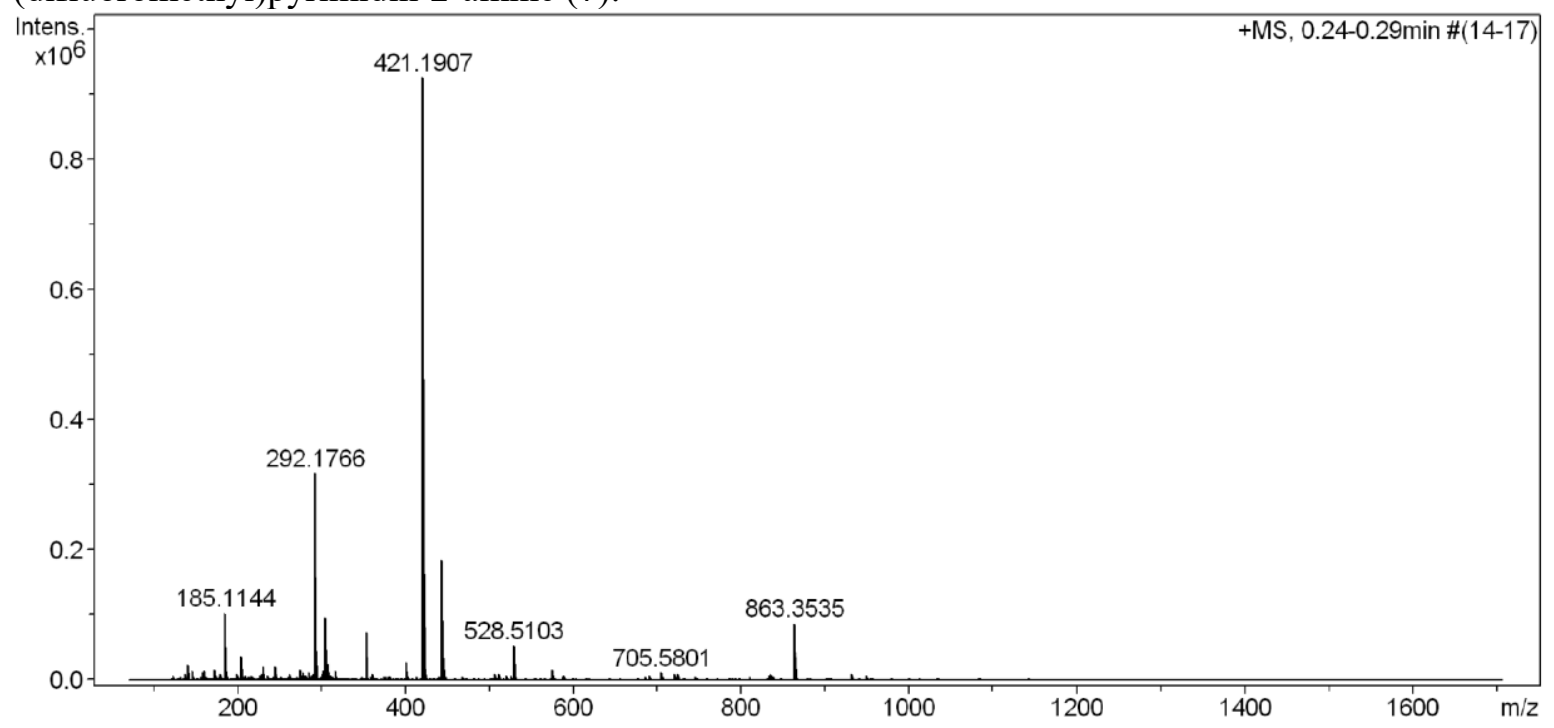

5-(4-((1R,5S)-8-oxa-3-azabicyclo[3.2.1]octan-3-yl)-6-morpholino-1,3,5-triazin-2-yl)-4(difluoromethyl)pyrimidin-2-amine (8):

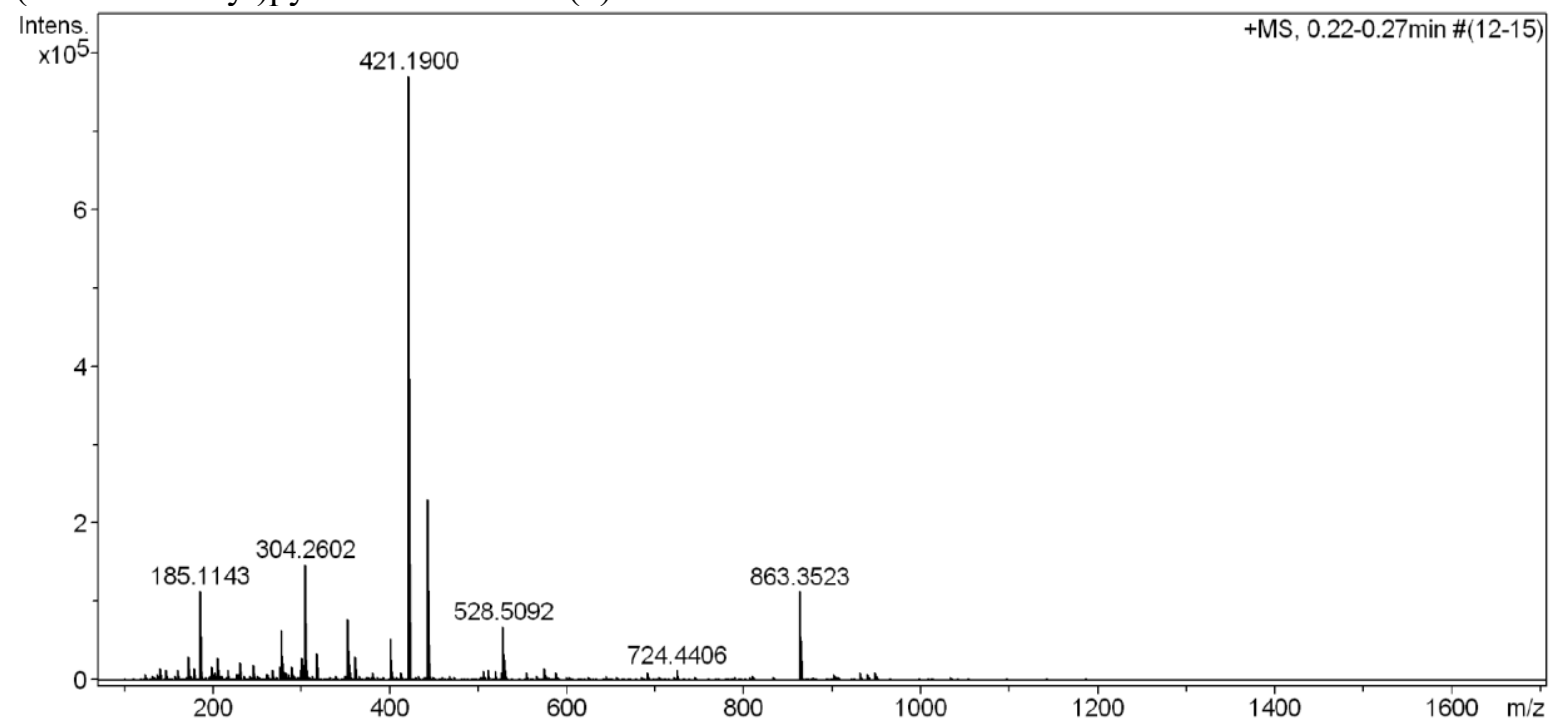


HPLC Chromatograms Final Compounds.

4-(difluoromethyl)-5-(4,6-dimorpholino-1,3,5-triazin-2-yl)pyrimidin-2-amine (PQR514, 4):

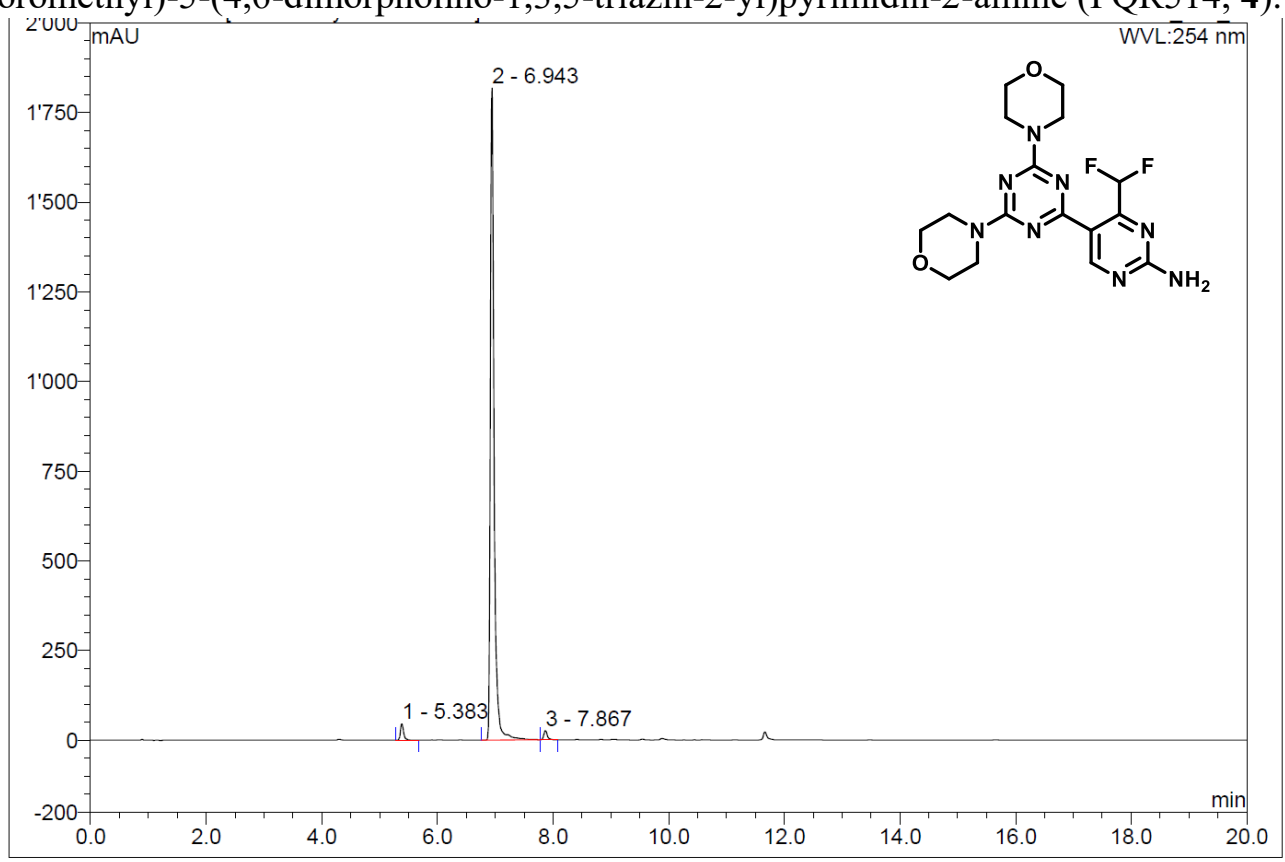

\begin{tabular}{|r|ccrrrrr|}
\hline No. & $\begin{array}{c}\text { Ret.Time } \\
\text { min }\end{array}$ & Peak Name & $\begin{array}{c}\text { Height } \\
\text { mAU }\end{array}$ & $\begin{array}{c}\text { Area } \\
\text { mAU*min }\end{array}$ & $\begin{array}{r}\text { Rel.Area } \\
\%\end{array}$ & Amount & Type \\
\hline 1 & 5.38 & n.a. & 45.183 & 2.901 & 2.05 & n.a. & BMB \\
2 & 6.94 & n.a. & 1818.030 & 136.984 & 96.68 & n.a. & BMB \\
3 & 7.87 & n.a. & 25.361 & 1.810 & 1.28 & n.a. & BMB \\
\hline Total: & & & 1888.574 & 141.695 & 100.00 & 0.000 & \\
\hline
\end{tabular}

(R)-4-(difluoromethyl)-5-(4-(3-methylmorpholino)-6-morpholino-1,3,5-triazin-2-yl)pyrimidin-2amine (6):

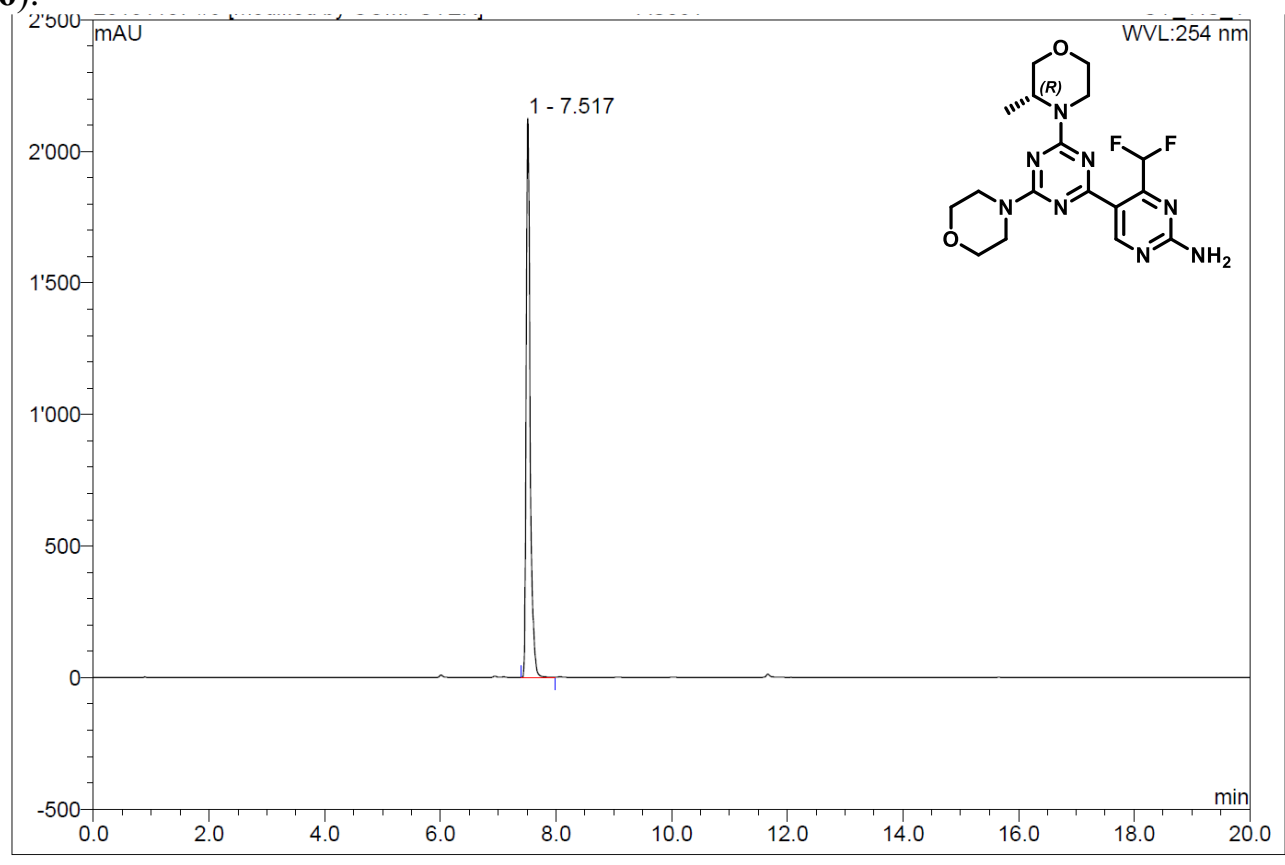

\begin{tabular}{|r|ccccccc|}
\hline No. & $\begin{array}{c}\text { Ret.Time } \\
\text { min }\end{array}$ & Peak Name & $\begin{array}{c}\text { Height } \\
\text { mAU }\end{array}$ & $\begin{array}{c}\text { Area } \\
\text { mAU*min }\end{array}$ & $\begin{array}{c}\text { Rel.Area } \\
\%\end{array}$ & Amount & Type \\
\hline 1 & 7.52 & n.a. & 2126.002 & 169.855 & 100.00 & n.a. & BMB \\
\hline Total: & & & 2126.002 & 169.855 & 100.00 & 0.000 & \\
\hline
\end{tabular}


5-(4-((1R,5S)-3-oxa-8-azabicyclo[3.2.1]octan-8-yl)-6-morpholino-1,3,5-triazin-2-yl)-4(difluoromethyl)pyrimidin-2-amine (7):

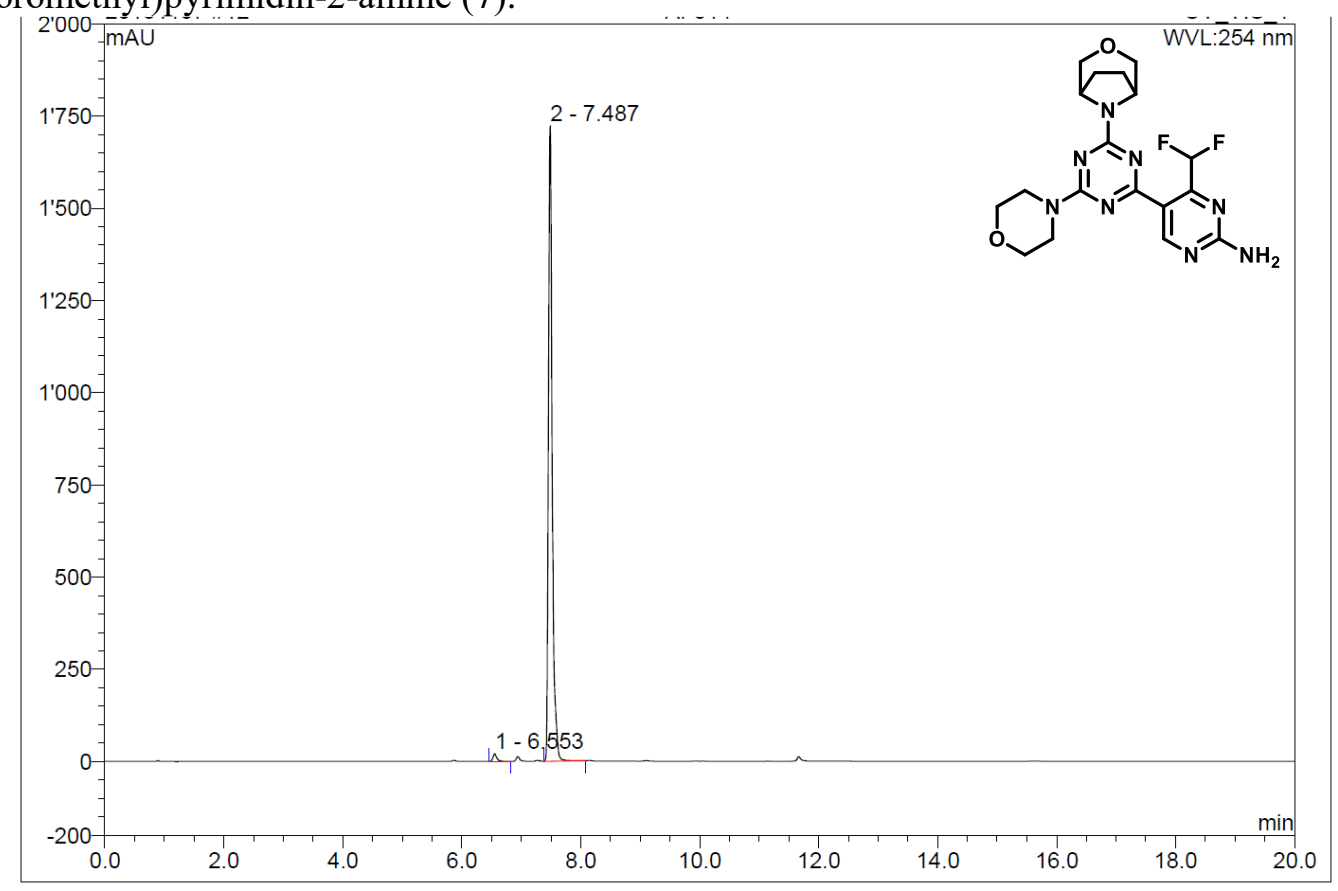

\begin{tabular}{|r|ccrrrrr|}
\hline No. & $\begin{array}{c}\text { Ret.Time } \\
\text { min }\end{array}$ & Peak Name & $\begin{array}{c}\text { Height } \\
\text { mAU }\end{array}$ & $\begin{array}{c}\text { Area } \\
\text { mAU*min }\end{array}$ & $\begin{array}{r}\text { Rel.Area } \\
\%\end{array}$ & Amount & Type \\
\hline 1 & 6.55 & n.a. & 20.105 & 1.474 & 1.15 & n.a. & BMB \\
2 & 7.49 & n.a. & 1723.058 & 126.956 & 98.85 & n.a. & BMB \\
\hline Total: & & & 1743.163 & 128.430 & 100.00 & 0.000 & \\
\hline
\end{tabular}

5-(4-((1R,5S)-8-oxa-3-azabicyclo[3.2.1]octan-3-yl)-6-morpholino-1,3,5-triazin-2-yl)-4(difluoromethyl)pyrimidin-2-amine (8):

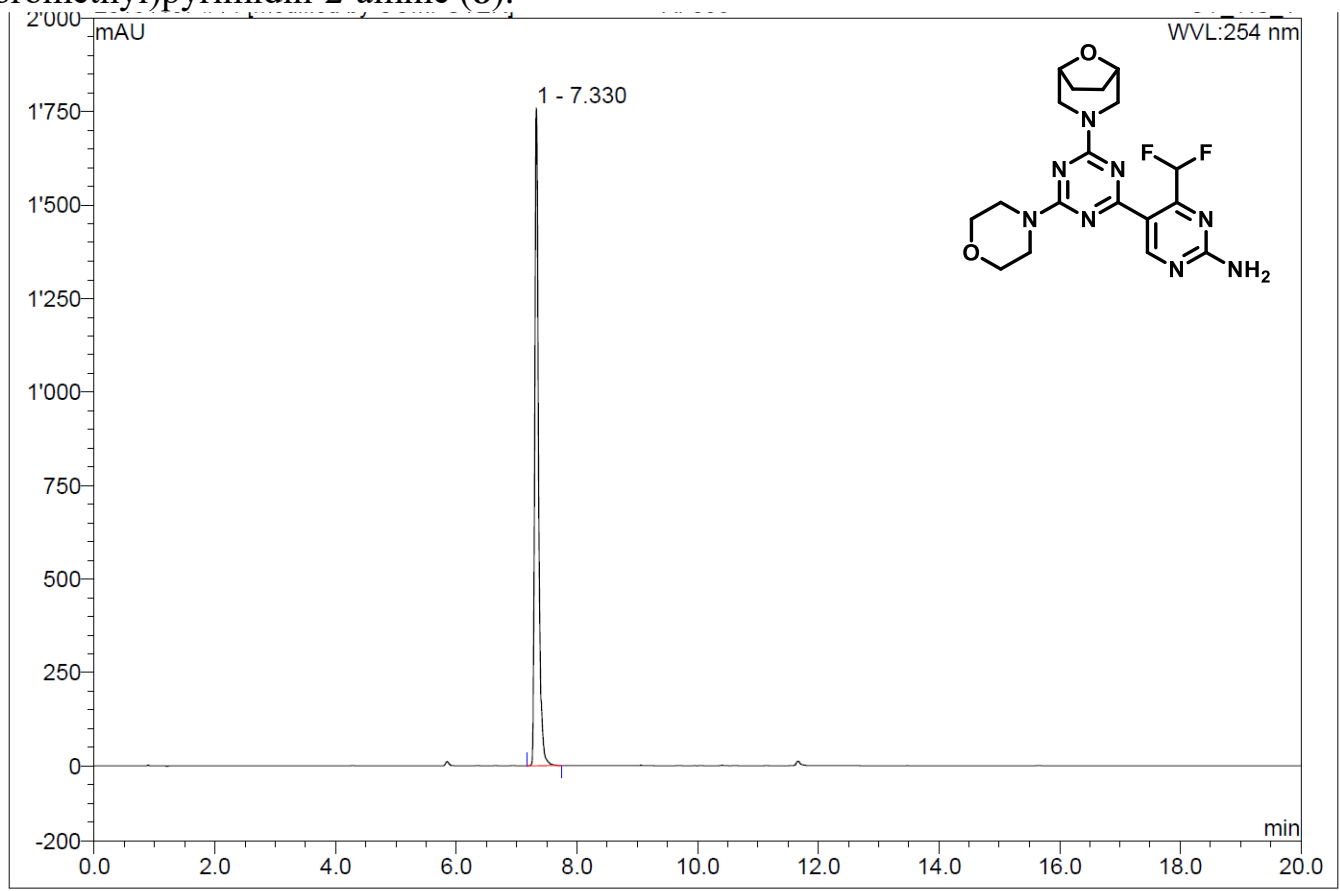

\begin{tabular}{|c|ccccccc|}
\hline No. & $\begin{array}{c}\text { Ret.Time } \\
\min \end{array}$ & Peak Name & $\begin{array}{c}\text { Height } \\
\text { mAU }\end{array}$ & $\begin{array}{c}\text { Area } \\
\text { mAU*min }\end{array}$ & $\begin{array}{c}\text { Rel.Area } \\
\%\end{array}$ & Amount & Type \\
\hline 1 & 7.33 & n.a. & 1759.229 & 127.710 & 100.00 & n.a. & BMB \\
\hline Total: & & & 1759.229 & 127.710 & 100.00 & 0.000 \\
\hline
\end{tabular}


Figure S2. Chemical structures
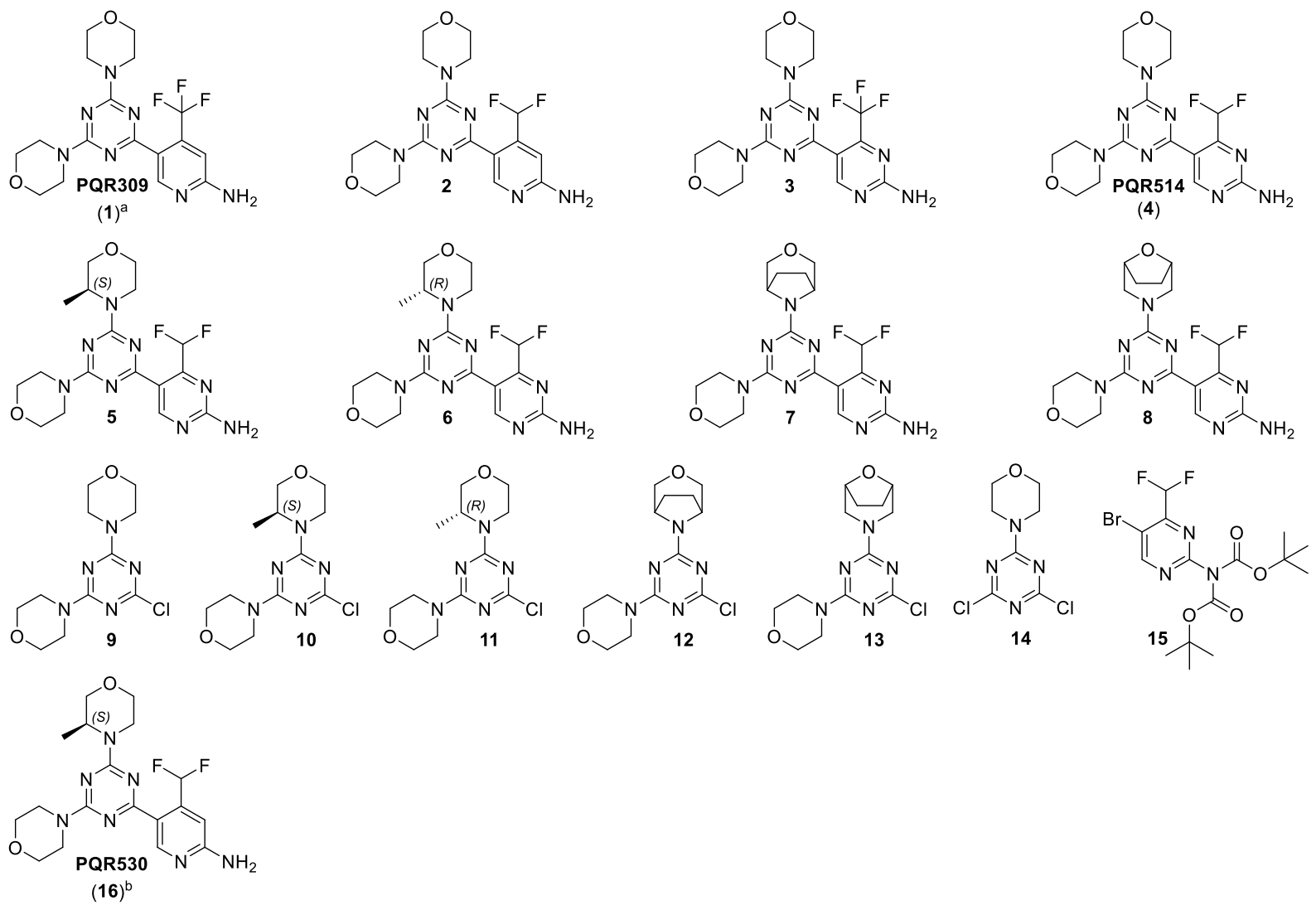

${ }^{\mathrm{a} C}$ Compound characterization from Ref. 10 and $11 .{ }^{\mathrm{b}}$ Compound characterization from Ref. 16. 